\title{
Origin and assessment of deep groundwater inflow in the Ca' Lita landslide using hydrochemistry and in situ monitoring
}

\author{
F. Cervi ${ }^{1}$, F. Ronchetti ${ }^{1}$, G. Martinelli ${ }^{3}$, T. A. Bogaard ${ }^{2}$, and A. Corsini ${ }^{1}$ \\ ${ }^{1}$ Department of Earth Sciences, University of Modena and Reggio Emilia, Italy \\ ${ }^{2}$ Department of Water Management, Delft University of Technology, The Netherlands \\ ${ }^{3}$ Regional Agency for the Protection of the Environment (ARPA), Emilia Romagna, Italy \\ Correspondence to: F. Cervi (federico.cervi@unimore.it)
}

Received: 9 May 2012 - Published in Hydrol. Earth Syst. Sci. Discuss.: 14 June 2012

Revised: 4 October 2012 - Accepted: 14 October 2012 - Published: 13 November 2012

\begin{abstract}
Changes in soil water content, groundwater flow and a rise in pore water pressure are well-known causal or triggering factors for hillslope instability. Rainfall and snowmelt are generally assumed as the main sources of groundwater recharge. This assumption neglects the role of deep water inflow in highly tectonized areas, a factor that can influence long-term pore-pressure regimes and play a role on local slope instability.

This paper aims to assess the origin of groundwater in the $\mathrm{Ca}$ ' Lita landslide (northern Italian Apennines) and to qualify and quantify the aliquot attributable to deep water inflow. The research is essentially based on in situ monitoring and hydrochemical analyses. It involved 5 yr of continuous monitoring of groundwater levels, electrical conductivity and temperature and with groundwater sampling followed by determination of major ions $\left(\mathrm{Na}^{+}, \mathrm{K}^{+}, \mathrm{Mg}^{2+}, \mathrm{Ca}^{2+}, \mathrm{Cl}^{-}, \mathrm{HCO}_{3}^{-}\right.$, $\mathrm{SO}_{4}^{2-}$ ), tracers (such as $\mathrm{B}_{\text {tot }}$ and $\left.\mathrm{Sr}^{2+}\right)$, and isotopes $\left(\delta^{18} \mathrm{O}\right.$, $\delta^{2} \mathrm{H}$ and ${ }^{3} \mathrm{H}$ ). Leaching experiments on soil samples, hydrochemical modelling and water recharge estimation were also carried out.

Results show that the groundwater balance in the $\mathrm{Ca}$ ' Lita landslide must take into account an inflow of deep and highly mineralised $\mathrm{Na}_{-} \mathrm{SO}_{4}$ water (more than $9500 \mu \mathrm{S} \mathrm{cm}^{-1}$ ) with non-negligible amounts of $\mathrm{Cl}^{-}$(up to $800 \mathrm{mgl}^{-1}$ ). The chemical and isotopic fingerprint of this water points to oilfield water hosted at large depths in the Apennine chain and that uprises through a regional fault line crossing the landslide area. It recharges the aquifer hosted in the bedrock underlying the sliding surface (at a rate of about 49000 $85700 \mathrm{~m}^{3} \mathrm{yr}^{-1}$ ) and it also partly recharges the landslide body. In both the aquifers, the hydrochemical imprint of deep
\end{abstract}

water mixed with rainfall and snowmelt water was observed. This indicates a probable influence of deep water inflow on the mobility of the Ca' Lita landslide, a finding that could be applicable to other large landslides occurring in highly tectonized areas in the northern Apennines or in other mountain chains. The paper demonstrates that hydrochemistry should, therefore, be considered as a valuable investigation method to define hydrogeological limits and the groundwater sources in hillslope and to assess groundwater flow patterns in deepseated landslides.

\section{Introduction}

Instability of hillslopes is generally triggered by hydrological and hydrogeological factors governing infiltration, increase of pore water pressure and resulting decreases in effective stress in the soil (Wieczorek, 1996; van Asch et al., 1999). In deep-seated landslides, effective groundwater infiltration on a slope scale over long periods of time can increase hydrostatic levels and determine groundwater flow, thus, playing an important role in the reactivation of slope movements (Hutchinson, 1970; Iverson and Major, 1987; van Asch et al., 1999).

However, the activation/reactivation of deep-seated landslides is a complex issue and groundwater recharge is not always due to precipitation alone. For instance, deep water upflow along regional tectonic structures can affect groundwater balance on a slope scale (Tóth, 2009). The presence of deep water into landslide deposits was reported in several cases in the northern Apennines (Colombetti and Nicolodi, 
1998; Bertolini and Gorgoni, 2001; Ciancabilla et al., 2004; Baraldi, 2008; Ronchetti et al., 2009) as well as in other mountain chains (Bonzanigo et al., 2001; de Montety et al., 2007).

Deep water can easily be detected by hydrochemical surveying (Bogaard et al., 2007) due to its very distinct chemical imprint depending on depth, temperature and pressure conditions, the mineral composition of hosting rocks or deposits, time of interaction between water and aquifer, and the mixing of different water types (Freeze and Cherry, 1979). However, differentiation of water types in hillslope hydrology is not often conducted (Guglielmi et al., 2000; Cappa et al., 2004). This paper deals with the analysis of groundwater in the $\mathrm{Ca}$ ' Lita landslide, a large rotational rock slideearth flow affecting highly tectonized flysch rock masses in the northern Italian Apennines. The landslide occurs along a major regional fault line, through which deep water inflow was proven to occur (Ronchetti et al., 2009). The aim is to assess the origin of groundwater below and inside the landslide, and to qualify and quantify the aliquot of groundwater from deep water inflow. The research makes combined use of groundwater monitoring and chemical/isotopic analyses. The results allow an assessment of the contribution of deep water to the hydrological processes and development of instability involved in the landslide.

\section{Hydrogeological and hydrochemical settings of the northern Apennines}

The northern Apennines (NA) are a fold-and-thrust mountain belt generated by the closure of the Ligure-Piemontese Ocean basin and the subsequent collision of the Adria and European continental plates (Boccaletti et al., 1971; Kligfield, 1979; Bettelli and Vannucchi, 2003; Molli, 2008). As a consequence of the polyphasic evolution of the accretionary wedge, the northern Apennines are made up of several tectono-stratigraphic units of marine sedimentary rocks, many of which are turbidite sequences (flysch rock masses) and clayey chaotic deposits (clayshales) (Fig. 1). Therefore, the hydrogeological setting of the northern Apennines is largely dominated by low permeability formations, which in many cases are to be considered as aquicludes unless they are affected by regional tectonic features inducing significant secondary permeability (Gargini et al., 2008). Limestone or gypsum formations acting as aquifers, that are quite common in the Alps, are indeed quite sporadic in the northern Apennines and they are prevalently exposed in the higher portion or at the front of the chain, far away from the case study where, in turn, permeable hydrogeological units are constituted by fractured and faulted turbidites-like formations.

More specifically, the Tuscan Units (TU), the Ligurian Units (LU) and the Sestola Vidiciatico Unit (SV) are mainly composed of thick and highly tectonized turbidite sequences (flysch rock masses) and clayey chaotic deposits

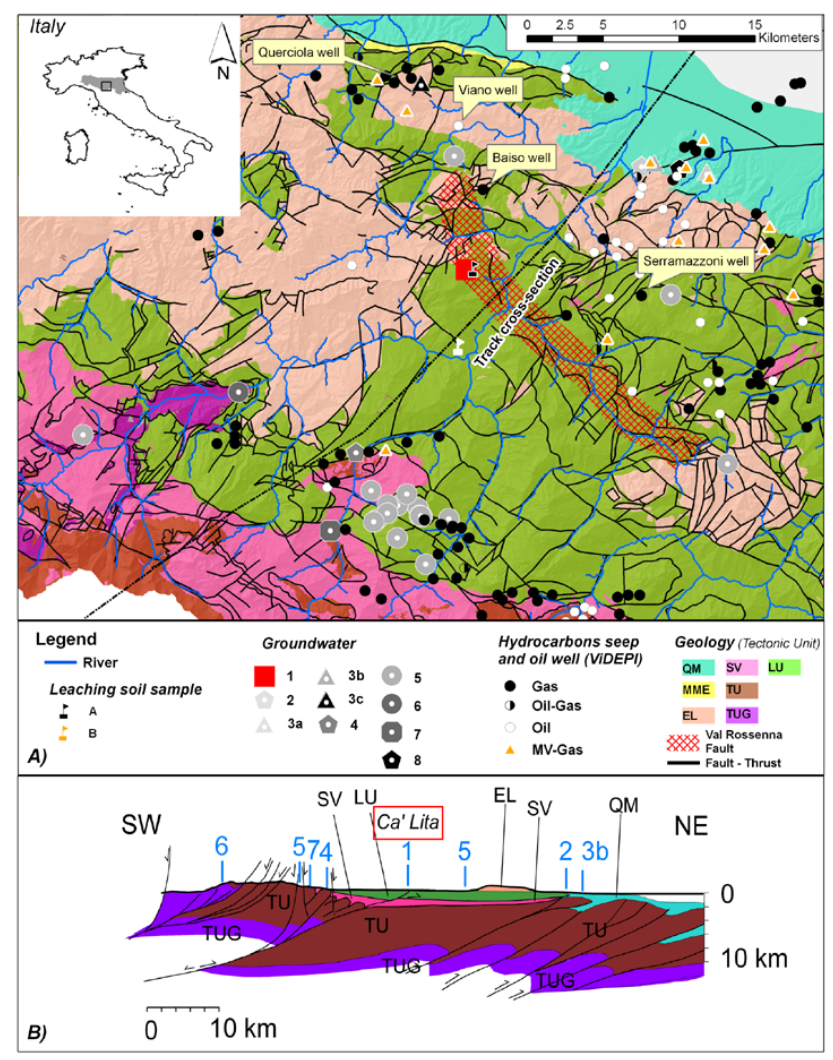

Fig. 1. (a) Simplified map of geologic units of the northern Apennines. (b) Geological cross section (modified after Vannucchi et al., 2008). Legend: geologic units (TU: Tuscan Units; TUG: Triassic Evaporites; LU: Ligurian units; EL: Epiligurian Units; SV: SestolaVidiciatico unit; MME: Messinian Evaporites; QM: Post Messinian Units). Water springs, water samples, hydrocarbon seeps and oil wells (1: Ca' Lita samples; 2: Salvarola baths; 3a: Mud volcano Nirano; 3b: Mud volcano Monte Gibbio; 3c: Mud volcano Regnano; 4: Quara baths; 5: Common shallow groundwater; 6: Poiano spring; 7: Morsiano spring; 8: Rio Petrolio hydrocarbon seep). Soil samples for leaching experiments (A: weathered Ca' Lita material; B: in situ rock outcrop).

(clayshales). Within these units, Triassic evaporites (TUG gypsum) are also found. The Epiligurian Units (EL) are mainly composed of turbidites (flysch rock masses). The Messinian and Post Messinian units, are made up of evaporites (MME gypsum) and marine clayey rocks (QM) outcropping at the front of the mountain chain. The main hydrogeological characteristics of these units and the typical hydrochemical imprint of hosted groundwater are described below.

\subsection{Tuscan Units (TU)}

Groundwater circuits developing within TU flysch rock masses are mostly shallow and widely distributed. The unconfined aquifers feed a large number of low-yield springs which discharge where the groundwater table crosses the 
land surface or a permeability contrast occurs. A deep regional groundwater flow system (Base Regional System BRS sensu Tóth, 1999) has recently been identified by Gargini et al. (2008): groundwater slowly (from $10^{-12}$ to $10^{-14} \mathrm{~m} \mathrm{~s}^{-1}$ ) flows from the upper NA chain toward the Po Plain. Supplied by rainfall and snowmelt water infiltrating near the watershed divide, the BRS is driven by regional gradients, but in some cases tectonic lineaments or topography concentrate discharge in isolated springs or directly into stream beds. Systematic changes in the anion facies have been reported: fresh infiltrated waters start from $\mathrm{HCO}_{3}$ (point no. 5 in Fig. 1a, b) and pass through $\mathrm{SO}_{4}$ (point no. 7 in Fig. 1a, b) finally reaching $\mathrm{Cl}$ (point no. 4 in Fig. 1a, b), while TDS (Total Dissolved Solids) increases up to 9$10 \mathrm{gl}^{-1} \cdot p \mathrm{CO}_{2}$ constantly increases up to $2.0 \mathrm{kPa}$. Water stable isotopes $\left(\delta^{18} \mathrm{O}\right.$ and $\left.\delta^{2} \mathrm{H}\right)$ range within precipitation values, shifted towards negative values, which characterise the higher recharge areas $\left(\delta^{18} \mathrm{O}\right.$ up to $-10.5 \%$ o to $-11 \%$ while $\delta^{2} \mathrm{H}$ can reach $-75 \%$ : Gargini et al., 2008). In the longest and deepest flow paths (main anion: $\mathrm{Cl}^{-}$), accumulation of trace ions, such as $\mathrm{B}_{\text {tot }}$ and $\mathrm{Sr}^{2+}$ and transported hydrocarbons and/or immiscible fluids (oil, gas) were noted (point no. 4 in Fig. 1a, b: Minissale et al., 2000; Capozzi and Picotti, 2002; Heinicke et al., 2010). In several cases $\mathrm{Sr}^{2+}$ and $\mathrm{B}_{\text {tot }}$ contents are strongly related; $\mathrm{B}_{\text {tot }}$, which can be mobilised from the organic matter buried during sedimentary processes, is normally associated with oilfield water if its value is in the order of $100 \mathrm{mgl}^{-1}$ (White, 1965) while $\mathrm{Sr}^{2+}$ ranges from 100 to $500 \mathrm{mg}^{-1}$ (Conti et al., 2000; Capozzi and Picotti, 2010).

\subsection{Sestola-Vidiciatico Unit, Ligurian Units and Epiligurian Units (SV, LU and EL)}

Moving towards the middle-front portion of the wedge, the SV and LU units can be considered impermeable (Vannucchi and Bettelli, 2010). Starting from the 1950s, the LU has been subjected to several drilling campaigns for intensive hydrocarbon investigations, whose results are collected inside the national VIDEPI Project database (UNIMIG, 2007). Many oil wells passing through the clayey formations (such as Viano, Baiso and Serramazzoni in Fig. 1a), found impregnation (even salience) of salt water (Na-Cl up to $9 \mathrm{gl}^{-1}$ ) together with oil and gas emission (methane, superior hydrocarbon, nitrogen) (Martinelli et al., 2011). Other spontaneous emissions (point no. 3c in Fig. 1a; Buttinelli et al., 2011) flowing out from the same unit show similar chemical characteristics (salinity up to $11 \mathrm{gl}^{-1}$ ). Their water isotopes are positive $\left(\delta^{18} \mathrm{O}\right.$ around $+5 \%$ ol $+6 \%$ ) while $p \mathrm{CO}_{2}$ stays around $1 \mathrm{kPa}$ (Conti et al., 2000; Capozzi and Picotti, 2010). EL flysch acts as an aquifer and stores $\mathrm{Ca}-\mathrm{HCO}_{3}$ water (point no. 5 in Fig. 1a, b). During the warm season springs provide discharge in the order of few $1 \mathrm{~s}^{-1}$ and low ion content (salinity is normally lower than $0.8 / 1 \mathrm{gl}^{-1}$ with $p \mathrm{CO}_{2}$ ranging from 0.6 to $1.9 \mathrm{kPa}$ ). The isotopic imprint corresponds to the local recharge area $\left(\delta^{18} \mathrm{O}\right.$ between $-8.5 \%$ and $-11 \%, \delta^{2} \mathrm{H}$ between $-55 \%$ and $-75 \%$ ) (Minissale et al., 2000; Cremaschi, 2008). $\mathrm{Sr}^{2+}$ is normally lower than $1 \mathrm{mgl}^{-1}$ while $\mathrm{B}_{\text {tot }}$ does not exceed $0.05 \mathrm{mg}^{-1}$ (Duchi et al., 2005; Toscani et al., 2001).

\subsection{Triassic (TUG) and Messinian (MME) evaporites}

In gypsum formations belonging to the TUG and MME, fresh water springs (point no. 6 in Fig. 1a, b) can originate. This water has high $\mathrm{SO}_{4}^{2-}$ values and, if the aquifer consists of halite, also $\mathrm{Cl}^{-}$. Salinity is normally higher than 2$3 \mathrm{~g} \mathrm{l}^{-1}$ while $\mathrm{Sr}^{2+}$ and $\mathrm{B}_{\text {tot }}$ contents are lower than $15 \mathrm{mg} \mathrm{l}^{-1}$ and $2 \mathrm{mg}^{-1}$, respectively (Chiesi et al., 2010; Duchi et al., 2005; Toscani et al., 2001). $p \mathrm{CO}_{2}$ is between 0.03$0.3 \mathrm{kPa}$. Isotope composition reflects the recharge altitude $\left(\delta^{18} \mathrm{O}\right.$ between $-8.5 \%$ and $-11 \%$ o, $\delta^{2} \mathrm{H}$ between $-55 \%$ and $-75 \%$ : Cervi, 2003).

\subsection{Post Messinian Units (QM)}

Along the boundary with the Po plain, several mud volcanoes (points 3a, b in Fig. 1a, b) affect the impermeable QM. These phenomena, which are widely observed along compressive margins around the world (Martinelli and Judd, 2004; Martinelli and Dadomo, 2005), consist of $\mathrm{Na}-\mathrm{Cl}$ waters (up to $90 \mathrm{gl}^{-1}$ ) flushing out particles of clay and entrapped connate water of the old Pliocene sea (Bonini, 2007). They originate from the buried QM-TU contact (located at a depth of more than $2000 \mathrm{~m}$ ), whereas oilfield fluids start to rise up towards the surface following inverse faults. Stable isotopes $\left({ }^{18} \mathrm{O}\right.$ and $\left.{ }^{2} \mathrm{H}\right)$ are sometimes highly positive $\left(\delta^{18} \mathrm{O}\right.$ up to $+5 \%$ and $\delta^{2} \mathrm{H}$ equal to $0 \%$ o) while $p \mathrm{CO}_{2}$ varies widely $(0.03-0.9 \mathrm{kPa})$. $\mathrm{B}_{\text {tot }}$ and $\mathrm{Sr}^{2+}$ can be as high as $300 \mathrm{mgl}^{-1}$ (Boschetti et al., 2010).

\subsection{Ca' Lita landslide settings}

The $\mathrm{Ca}$ ' Lita landslide is located between 640 and $230 \mathrm{~m}$ a.s.l. in the NE mountainside of the northern Apennines (coordinate: Lat. $44.458657^{\circ}$, Long. $10.626566^{\circ}$, Aspect $135^{\circ}$ North). Over the last $40 \mathrm{yr}$, the average annual rainfall in the area was $810 \mathrm{~mm} \mathrm{yr}^{-1}$ and the mean air temperature was $11.7^{\circ} \mathrm{C}$ (ARPA, 2010). Precipitation is distributed over 70 to 100 days $\mathrm{yr}^{-1}$ with two peaks: a main one in autumn (October-November) and a secondary one in spring (April). Fazlagic et al. (2004) report an average annual snowfall of about $42 \mathrm{~cm}$ from 1830 to 1998 . The Ca' Lita landslide affects a hillslope composed of formations belonging to the Ligurian Units (LU). One formation consists of poorly cemented sandstone flysch (MOH), another is composed of clayshales (MVR) (Fig. 2a, b). In the slope, the stratigraphic relation between MOH and MVR is complicated by the presence of a high angle regional fault (Papani et al., 2002) that is linked to a regional faults system (Val Rossenna fault as reported by Bettelli et al., 2002; Fig. 1a). The landslide can 
be classified as a reactivated complex landslide (WP/WLI, 1993; Cruden and Varnes, 1996), associating rotational rock slides in the crown and head zones (in the $\mathrm{MOH}$ formation) with earth flows in the lower main body (in the MVR formation). The total length is $2.7 \mathrm{~km}$ with a mean slope angle of $15^{\circ}$ and a total estimated volume of $40 \mathrm{Mm}^{3}$. The area involved by the retrogressive rotational slide movements is $0.5 \mathrm{~km}^{2}$ and it extends from 640 to $475 \mathrm{~m}$ a.s.l. over a length of $525 \mathrm{~m}$ (Fig. 2a, b). It was reactivated several times in the last century (Borgatti et al., 2006; Corsini et al., 2009). Recently, it resumed activity in 2002 and underwent paroxysmal phases in winter 2003 and spring 2004 due to $200 \mathrm{~mm}$ of cumulated rainfall in the two preceding months combined with the rapid melting of about $80 \mathrm{~cm}$ of snow. After the 2004 event, an extensive geological investigation and monitoring campaign was set up in order to design mitigation structures (Corsini et al., 2006). Boreholes and inclinometers showed that the active rock slide deposit had a maximum thickness of 44-48 $\mathrm{m}$ while the active earth flow deposit had a mean thickness of about $10 \mathrm{~m}$ (Borgatti et al., 2006). Since summer 2006, no further deep seated rock slide movements have been recorded and only shallow slides have occurred close to the main scarps. Later, inclinometers and 5 standpipe piezometers were installed and equipped with pressure transducers. Electrical conductivity probes were also installed inside two of these. Piezometers were used in the research as groundwater monitoring and sampling points. Other monitoring and sampling points were drainage wells and subhorizontal drains constructed during mitigation work at different locations on the slope (Fig. 2a, b).

Deep drainage wells in the rock slide (Borgatti et al., 2008) drain groundwater from the landslide body and convey it to well A (WA in Fig. 2a, b), from where it is removed by pumping. At the base of the frontal scarp of the rock slide zone, a shield of shallow drainage wells drain water from the superficial debris and convey it to drainage point B (DrB in Fig. 2a, b). In the same area, a set of sub-horizontal drains of length from 50-100 $\mathrm{m}$ drain water from the bedrock below the sliding surface and convey it to drainage point A (DrA in Fig. 2a, b).

The in situ characterisation performed by Ronchetti et al. (2009) highlighted high heterogeneity of the hydrogeological characteristics of flysch bedrock and of landslide materials, which are affected at different depths by discontinuities that act as zones of preferential flow. In situ slug tests and pumping tests were used to estimate the hydraulic conductivity of the different units. The flysch bedrock has a hydraulic conductivity in the range $10^{-6} / 10^{-7} \mathrm{~m} \mathrm{~s}^{-1}$, the main landslide body (made of disarranged flysch rock masses) $10^{-5} / 10^{-6} \mathrm{~m} \mathrm{~s}^{-1}$ and the clayshales less than $10^{-8} \mathrm{~m} \mathrm{~s}^{-1}$. According to Civita (2005), the infiltration coefficient $\left(I_{\mathrm{c}}\right)$ ranges from 0.4 to 0.7 for flysch and the main landslide body and can be considered negligible for the clayshales.

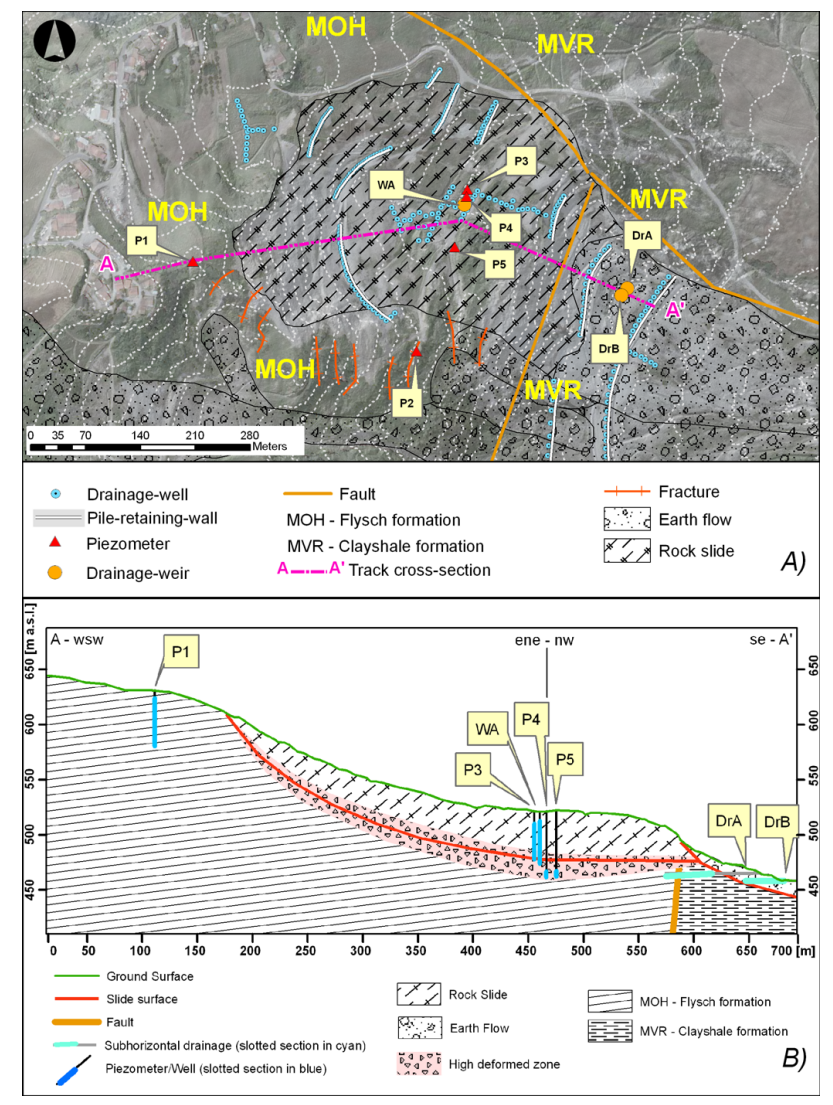

Fig. 2. (a) Geological sketch of Ca' Lita landslide. Location of the monitoring points: drainage systems DrA, DrB, WA; piezometers P1, P3, P4, P5. (b) Geological cross-section of Ca' Lita with drainage works and piezometers.

\section{Methods}

With reference to the case study, an interdisciplinary investigation was performed. It consisted of several steps involving hydrological (groundwater level and discharge monitoring, estimation of the groundwater balance for several hydrologic years), hydrochemical (groundwater conductivity monitoring, groundwater isotopic and chemical analyses, leaching experiments, hydrochemical modelling), and mineralogical (soil composition) surveys. More specifically, the groundwater chemistry and stable isotope contents were characterised in order to assess end-members and mixing phenomena. Based on existing local databases, the reference isotopic values $\left(\delta^{18} \mathrm{O}\right.$ and $\left.{ }^{3} \mathrm{H}\right)$ for rainfall recharge water were defined. An independent validation, to check if the peculiar water chemistry could be due only to the mineralogy of the site, consisted in leaching experiments with soil samples belonging to the two outcropping geological formations. In addition, equilibrium-based model PHREEQC (Parkhurst and Appelo, 2004) was defined in order to simulate the long-term chemical interaction between rainfall water and host rocks. The aliquot of deep water was estimated by coupling radioactive isotopes content with groundwater balance. 


\subsection{Groundwater level, conductivity and discharge monitoring}

The 5 standpipe piezometers are slotted at different depths and monitor groundwater in the bedrock at the crown and along the side of the rock slide (P1, P2), inside the rock slide body (P3), and across the deepest sliding surface (P4, P5) (Fig. 2a, b). The characteristics of the boreholes are reported in Table 1.

They have been equipped with pressure transducers since 2005 in order to monitor Groundwater Levels $\left(\mathrm{GW}_{\mathrm{L}}\right)$ with an acquisition frequency of $1 \mathrm{~h}$. Groundwater Electrical Conductivity $\left(\mathrm{GW}_{\mathrm{EC}}\right)$ was measured from June 2009 to March 2010, with an acquisition frequency of $6 \mathrm{~h}$ in P3 and P4. In the other piezometers, $\mathrm{GW}_{\mathrm{EC}}$ and Groundwater Temperatures $\left(\mathrm{GW}_{\mathrm{T}}\right)$ were measured periodically from 2006 to 2009 and from 2010 to date.

The discharge of groundwater drained by the wells from inside the rock slide body was monitored from 2007 to 2010 by means of a graduated weir located at the outlet of the WA pumping system. The discharge of groundwater drained by sub-horizontal drains from the bedrock underneath the main rock sliding surface was monitored from 2006 to 2009 by means of a graduated weir located at the outlet of DrA. In WA and DrA, the $\mathrm{GW}_{\mathrm{EC}}$ and the $\mathrm{GW}_{\mathrm{T}}$ were measured seasonally from 2006 to August 2010. The physical-chemical parameters were checked using a Crison MM40+ multimeter equipped with a Ross glass electrode for $\mathrm{pH}$.

\subsection{Groundwater chemical analyses}

Groundwater sampling was conducted in 2006 (sampling campaign A), 2007 and 2009 (sampling campaigns B and $\mathrm{D}$; red square in Fig. $3 \mathrm{~b}$ ). All the 5 standpipe piezometers and both DrA and DrB were sampled. All samples were collected using bailers except samples collected during summer 2009 from DrA and P1, which were collected using a low-flow pump $\left(0.11 \mathrm{~s}^{-1}\right)$ after removing the standing water in the piezometer. Water for laboratory study was filtered through $0.45 \mu \mathrm{m}$ cellulose membranes, and the aliquot for cation analysis was acidified with $65 \% \mathrm{HNO}_{3}$ Suprapur Merck. Analyses were conducted to establish major ion concentrations $\left(\mathrm{K}^{+}, \mathrm{Na}^{+}, \mathrm{Ca}^{2+}, \mathrm{Mg}^{2+}, \mathrm{Cl}^{-}, \mathrm{SO}_{4}^{2-}\right.$ and $\left.\mathrm{HCO}_{3}^{-}\right)$ as well as the $\mathrm{B}_{\text {tot }}$ and $\mathrm{Sr}^{2+}$ contents. Cation contents were assessed by atomic absorption spectrometry (Spectr AA-640, Varian). Anions were determined using an HPLC (high performance liquid chromatography, Dionex DX-120). Total alkalinity was assessed by Gran titration (Gran, 1952). Data are reported in $\mathrm{mgl}^{-1}$ (Table 3). The total relative uncertainty is less than $5 \%$ for all compounds.

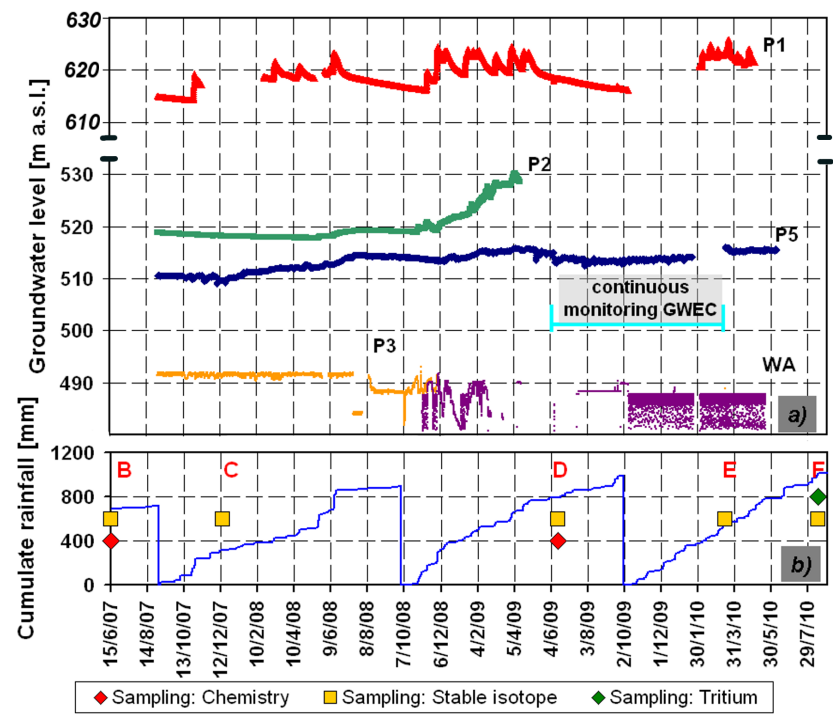

Fig. 3. (a) Continuous groundwater level $\left(\mathrm{GW}_{\mathrm{L}}\right)$ monitoring for piezometers P1, P2, P3, P5 and drainage well WA. (b) Cumulative rainfall for each hydrologic year. Chemical (red square) and isotopic (yellow diamond: stable isotopes; green diamond: tritium) sampling campaigns are reported.

\subsection{Groundwater isotopic analyses}

Stable oxygen and hydrogen isotope analyses $\left(\delta^{18} \mathrm{O}, \delta^{2} \mathrm{H}\right)$ were carried out by mass spectrometry on water samples collected from all the piezometers and DrA. Five sampling campaigns scattered over $5 \mathrm{yr}$ were conducted starting from 2006 (sampling campaigns A, B, C, D, E, F; yellow diamond in Fig. 3b). The samples represent the summer (A, B, D, $\mathrm{F}$ ), winter (C), and spring (E) periods. The results are reported as differences between the sample and the standard (Vienna Standard Mean Oceanic Water: V-SMOW). This deviation is presented in the standard $\delta$-notation as per mil $(\%)$ where $\delta=\left[\left(R_{\mathrm{S}} / R_{\mathrm{SMOW}}\right)-1\right] 1000 ; R_{\mathrm{S}}$ represents either the ${ }^{18} \mathrm{O} /{ }^{16} \mathrm{O}$ or the ${ }^{2} \mathrm{H} /{ }^{1} \mathrm{H}$ ratio of the sample, and $R_{\mathrm{SMOW}}$ is ${ }^{18} \mathrm{O} /{ }^{16} \mathrm{O}$ or the ${ }^{2} \mathrm{H} /{ }^{1} \mathrm{H}$ ratio of the SMOW. The precisions are in the order of $\pm 0.05 \%$ o $\left(\delta^{18} \mathrm{O}\right)$ and $\pm 0.7 \% \circ\left(\delta^{2} \mathrm{H}\right)$. Deuterium excess values were calculated according to Dansgaard (1964) as $d=\delta^{2} \mathrm{H}-8 \cdot \delta^{18} \mathrm{O}$.

Tritium analysis $\left({ }^{3} \mathrm{H}\right)$ of groundwater was carried out on samples collected in August 2010 from DrA (sampling campaign F; green diamond in Fig. 3b). Water samples from DrA were selected as representative of water that can discharge, by natural or artificial drainage, from the deepest and longest circulation path developed through the slope. Analysis was performed using the electrolytic enrichment and liquid scintillation counting method (Thatcher et al., 1977). Results were expressed as Tritium Units (T.U. in which one T.U. equals one tritium atom per $10^{18}$ hydrogen atoms). Analytical errors are in the order of \pm 0.2 T.U. 
Table 1. Characteristics of piezometers, wells and drainage systems in Ca' Lita landslide. Location in the landslide area, material, depth of the filters, depth of the main slide surface, type of monitoring are also reported.

\begin{tabular}{|c|c|c|c|c|c|c|c|}
\hline Name & Location & Material & $\begin{array}{l}\text { Altitude } \\
\text { (ma.s.l.) }\end{array}$ & $\begin{array}{l}\text { Slotted } \\
\text { from- } \\
\text { to }(\mathrm{m})\end{array}$ & $\begin{array}{l}\text { Depth of } \\
\text { the main } \\
\text { sliding } \\
\text { surface }(m)\end{array}$ & $\begin{array}{l}\text { Continuous } \\
\text { level/discharge } \\
\text { monitoring }\end{array}$ & $\begin{array}{r}\text { Continuous } \\
\text { conductivity- } \\
\text { monitoring }\end{array}$ \\
\hline $\mathrm{P} 1$ & Crown & Flysch & 631 & $9-50$ & & $\checkmark$ & \\
\hline P2 & Right flank & Fractured Flysch & 539 & $4-59$ & $17-35$ & $\checkmark$ & \\
\hline P3 & Head (main boby) & Rock blocks in clay-silt matrix & 520 & $3-44$ & 44 & $\checkmark$ & $\checkmark$ \\
\hline P4 & Head (below the main slide surface) & Fractured Flysch & 520 & $50-59$ & 44 & $\checkmark$ & $\checkmark$ \\
\hline P5 & Head (below the main slide surface) & Fractured Flysch & 525 & $55-60$ & 48 & $\checkmark$ & \\
\hline WA & Head (main boby) & Rock blocks in clay-silt matrix & 521 & $50-59$ & 44 & $\checkmark$ & \\
\hline DrA & Secondary scarp & Flysch & 465 & about 55 & 44 & $\checkmark$ & \\
\hline DrB & Secondary scarp & Rock blocks in clay-silt matrix & 455 & about 13 & 13 & & \\
\hline
\end{tabular}

\subsection{Definition of reference isotopic values for rainfall recharge water}

In recent years, no station of the Global Network of Isotopes in Precipitation (GNIP) of the International Atomic Energy Agency (IAEA) located in the proximity of the study site measured $\delta^{18} \mathrm{O}$ and ${ }^{3} \mathrm{H}$ values (WISER, 2012). In particular, the San Pellegrino Alpe station (1520 m a.s.l., about $30 \mathrm{~km}$ south-west of Ca' Lita) has monthly records of $\delta^{18} \mathrm{O}$ from 1993 to 2002 and of ${ }^{3} \mathrm{H}$ from 1994 to 1995, while the Bologna station ( $35 \mathrm{~m}$ a.s.l. about $50 \mathrm{~km}$ north-east of Ca' Lita.) has only a monthly record of $\delta^{18} \mathrm{O}$ from 1996 to 2000.The isotopic values in these records are too distant in time to be used as reference values for the 2006-2010 analysis period.

With reference to rainfalls in northern Apennines, Longinelli and Selmo (2003) reported a mean annual $\delta^{18} \mathrm{O}$ value in the period 1993-2002 around $-7 \%$ to $-8 \%$ along the Po Plain (about $30 \mathrm{~m}$ a.s.1.) increasing up to $-10 \%$ near the highest relief (about $2100 \mathrm{~m}$ a.s.1.) with a mean altitude effect of about $-0.2 \% \circ \delta^{18} \mathrm{O} / 100 \mathrm{~m}$. By considering the years 2006-2007-2008, Cremaschi (2008) found an average isotopic gradient of about $-0.1 \% \circ \delta^{18} \mathrm{O} / 100 \mathrm{~m}$ for the same area. This is in agreement with Longinelli et al. (2006), which reported more depleted values of $\delta^{18} \mathrm{O}$ in precipitations over the Po Plain areas during years 2002, 2003 and 2004 which were characterised by high temperatures. Considering these altitude gradients, a mean annual $\delta^{18} \mathrm{O}$ value for precipitations in $\mathrm{Ca}$ ' Lita should not be more negative than $-8.5 /-9 \%$. Anyway, Iacumin et al. (2009) reported the $\delta^{18} \mathrm{O}$ values for shallow groundwater (sampled in wells and springs) and rivers in northern Apennines. In rivers, monthly $\delta^{18} \mathrm{O}$ observations from 2004 to 2006 varied from $-9.8 \%$ (winter) to $-6.8 \%$ (summer). In shallow groundwater, monthly $\delta^{18} \mathrm{O}$ observations varied between maximum of $-8.0 \%$ o to minimum of $-8.7 \%$. The authors concluded that springs and wells provided smoothed records of $\delta^{18} \mathrm{O}$ compared to the river and the isotopic values are shifted towards more negative values. This is due to a homogenisation effect made by the flysch aquifers on the isotopic signal of rainfalls, together with the inability of summer rainfalls to reach the groundwater. Similarly, Minissale and Vaselli (2011) reported for central Italy that springs can be used to provide a mean annual isotopic value of rainfall recharge water. Based on Iacumin et al. (2009), a mean annual $\delta^{18} \mathrm{O}$ value for the Ca' Lita landslide could be even more negative than those reported taking into account the mean isotopic gradients. Given these uncertainties, and considering that some of the samples collected in Ca' Lita might actually represent rainfall water just after a shallow infiltration, the reference $\delta^{18} \mathrm{O}$ of rainfall water was estimated graphically in a $\delta^{18} \mathrm{O}-\delta^{2} \mathrm{H}$ plot (as suggested by Gibson et al., 2005) as the intersection point between the line defined by the groundwater samples in Ca' Lita and the meteoric line for north Italy proposed by Longinelli and Selmo (2003). Other springs with similar elevation recharge area of Ca' Lita were sampled and analysed to provide further comparison and the results confirmed the reference $\delta^{18} \mathrm{O}$ value of $-9.90 \%$.

With respect to reference ${ }^{3} \mathrm{H}$ values for rainfall water, the ARPA Emilia-Romagna ${ }^{3} \mathrm{H}$ data (ARPA, 2009) was considered as representative of rainfall recharge water. This database includes three-monthly ${ }^{3} \mathrm{H}$ values for water samples collected in the hydrologic year 2008-2009 just a few $\mathrm{km}$ north of the Ca' Lita landslide. The ${ }^{3} \mathrm{H}$ dataset from ARPA can be considered an isotopic marker of rainfall. It refers to water sampled in a very shallow well (depth of $20 \mathrm{~m}$ ) in an unconfined gravel aquifer which is directly recharged by Secchia river water. This ${ }^{3} \mathrm{H}$ record, obtained using the same analytical method used in Ca' Lita, shows that T.U. is on average of 9.8 T.U., with small variability throughout the year. This value is comparable to the monthly weighted average of 8.4 T.U. measured by Tazioli (2011) in the 20082009 period in a rain-gauge located in the eastern-sector of the Apennines. The slight discrepancy between the ${ }^{3} \mathrm{H}$ rainfall-recharge values measured by ARPA (2009) and Tazioli (2011) can be explained as a result of the different atmospheric/precipitation regimes between coastal and continental stations (Ferronsky and Polyakpov, 2012) which results in 
Table 2. Piezometer monitoring results and total-effective rainfall. Data are distinguished by hydrologic year.

\begin{tabular}{|c|c|c|c|c|c|c|c|c|}
\hline $\mathrm{Pz}$ & $\begin{array}{l}\text { Hydrologic } \\
\text { year }\end{array}$ & $\begin{array}{r}\mathrm{GW}_{\mathrm{L}} \\
\max \\
\text { (m a.s.1.) }\end{array}$ & $\begin{array}{r}\mathrm{GW}_{\mathrm{L}} \\
\mathrm{min} \\
\text { (m a.s.1.) }\end{array}$ & $\begin{array}{r}\mathrm{GW}_{\mathrm{L}} \max - \\
\mathrm{GW}_{\mathrm{L}} \min \\
(\mathrm{m})\end{array}$ & $\begin{array}{l}\text { Mean } \\
\mathrm{GW}_{\mathrm{L}}\end{array}$ & $\begin{array}{r}\text { Mean air } \\
\text { temp } \\
\left({ }^{\circ} \mathrm{C}\right)\end{array}$ & $\begin{array}{r}\text { Total } \\
\text { rainfall } \\
(\mathrm{mm})\end{array}$ & $\begin{array}{r}\text { Total-effective } \\
\text { rainfall } \\
(\mathrm{mm})\end{array}$ \\
\hline $\mathrm{P} 1$ & 2005-2006 & 623.62 & 616.16 & 8.71 & 618.39 & 12.3 & 880 & 273 \\
\hline $\mathrm{P} 2$ & & 523.35 & 520.70 & 2.65 & 522.22 & & & \\
\hline P3 & & - & - & - & 491.76 & & & \\
\hline P4 & & 513.77 & 508.98 & 4.79 & 510.16 & & & \\
\hline P5 & & - & 508.47 & - & - & & & \\
\hline $\mathrm{P} 1$ & 2006-2007 & 621.19 & 614.33 & 6.86 & 616.03 & 14.5 & 763 & 49 \\
\hline $\mathrm{P} 2$ & & 520.7 & 518.42 & 2.28 & 519.46 & & & \\
\hline P3 & & - & - & - & 490.19 & & & \\
\hline $\mathrm{P} 4$ & & 509.75 & 508.33 & 1.42 & 508.5 & & & \\
\hline P5 & & 510.79 & 509.72 & 1.07 & 510.4 & & & \\
\hline $\mathrm{P} 1$ & 2007-2008 & 623.33 & 616.24 & 7.09 & 618.14 & 12.7 & 845 & 299 \\
\hline $\mathrm{P} 2$ & & 519.19 & 517.99 & 1.2 & 518.41 & & & \\
\hline P3 & & - & - & - & 488.73 & & & \\
\hline $\mathrm{P} 4$ & & 513.65 & 502.43 & 11.22 & 508.96 & & & \\
\hline P5 & & 512.21 & 507.89 & 4.32 & 510.97 & & & \\
\hline $\mathrm{P} 1$ & 2008-2009 & 624.47 & 616.18 & 8.29 & 619.37 & 12.7 & 893 & 447 \\
\hline $\mathrm{P} 2$ & & 526.93 & - & - & - & & & \\
\hline P3 & & - & - & - & 488.5 & & & \\
\hline $\mathrm{P} 4$ & & 518.10 & 508.21 & 9.89 & 512.33 & & & \\
\hline P5 & & 513.56 & 511.60 & 2.15 & 512.27 & & & \\
\hline $\mathrm{P} 1$ & 2009-2010 & 624.90 & - & - & - & 12.5 & 1152 & 347 \\
\hline $\mathrm{P} 2$ & & - & - & - & - & & & \\
\hline P3 & & - & - & - & 488.50 & & & \\
\hline P4 & & 518.26 & - & - & - & & & \\
\hline P5 & & 514.17 & - & - & - & & & \\
\hline
\end{tabular}

the relative enrichment of ${ }^{3} \mathrm{H}$ for the northern Italian Po-plain rain-gauges stations quantified in about $20 \%$ by Dadomo and Martinelli (2005).

\subsection{Leaching analyses}

Four soil samples from the two different geological formations (MVR and MOH) were collected from in-situ outcrops (about $7 \mathrm{~km}$ south of Ca' Lita, Fig. 1a: MVRb and MOHb) and regolith (i.e., weathered material still in its original location at Ca' Lita, Fig. 1a: MVRa and $\mathrm{MOHa}$ ). According to the USGS field leach test procedures (USGS, 2005), $50 \mathrm{~g}$ of dried material for each sample was sieved less than $2 \mathrm{~mm}$ and leached into 11 of deionized water, continuously shaken by a magnetic agitator (with a constant rotation speed of $200 \mathrm{rpm}$ ). The experiments extended over a maximum of $10 \mathrm{~h}$ while an electrical conductivity probe was used to monitor water mineralisation on a fixed time-table $(30 \mathrm{~s}, 1 \mathrm{~min}$, $2 \mathrm{~min}, 5 \mathrm{~min}, 10 \mathrm{~min}, 30 \mathrm{~min}, 1 \mathrm{~h}, 10 \mathrm{~h}$ ). Each water sample was collected after $1 \mathrm{~h}$ of interaction to determine the major ion contents.

\subsection{Mineralogical analyses and PHREEQC modelling}

The mineralogy was investigated using 2 soil samples collected at $\mathrm{Ca}$ ' Lita (MOHa, MVRa). The analysis of the $<2 \mu \mathrm{m}$ fraction was conducted using X-ray diffractometry on oriented paste. Starting from these two mineralogical assemblages, the PHREEQC model (Parkhurst and Appelo, 2004) simulates the interaction (precipitation and dissolution of phases) with an aqueous solution (specifically: rain water with a mean temperature equal to the mean annual air temperature of the site, i.e., $11.7^{\circ} \mathrm{C}$ and $\mathrm{pH}=5.8$ ) until equilibrium is reached.

\subsection{Isotopic groundwater balance}

The mean annual groundwater recharge from rainfall was estimated using rainfall and temperature data over the last $40 \mathrm{yr}$ derived from available official ARPA Emilia Romagna rainfall databases (ARPA, 2010) for the nearest weather station (Baiso), located $4.5 \mathrm{~km}$ northwest of Ca' Lita with the same elevation and aspect. The Thornthwaite and Mather (1957) formula was used to assess the potential mean annual evapotranspiration. Total groundwater recharge volume was calculated by multiplying the water surplus for the slope recharge area. The mean annual deep water inflow was estimated by 


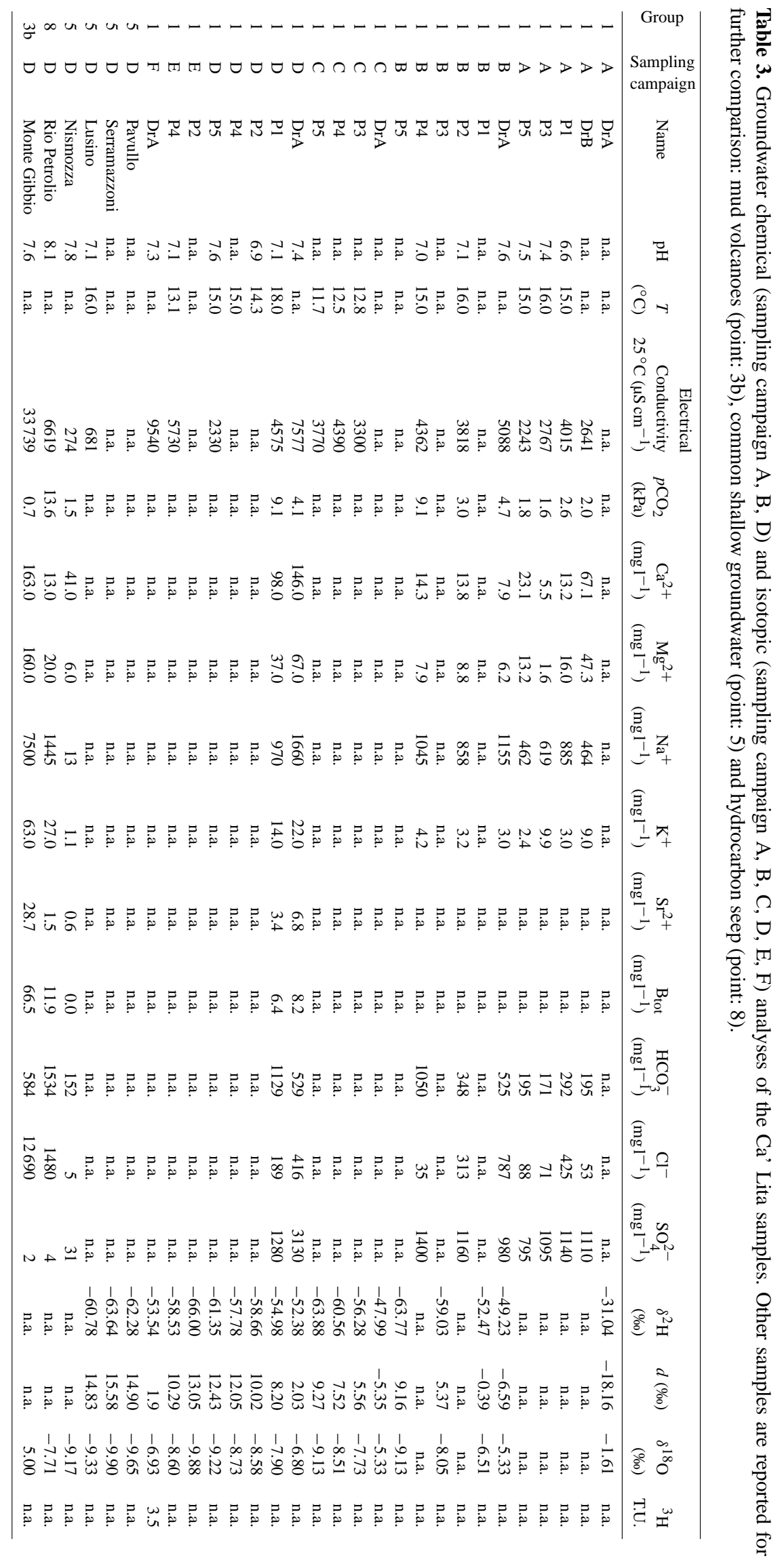


solving a simplified annual water-balance equation and by processing the ${ }^{3} \mathrm{H}$ data as described by Mazor (1997). In particular, the aliquot of deep water stored inside the aquifer (groundwater aliquot $a$ ) was estimated by considering a ${ }^{3} \mathrm{H}$ of deep water $\left({ }^{3} \mathrm{H}_{\mathrm{dw}}\right)$ equal to 0 T.U., starting from Eq. (1):

$a \cdot{ }^{3} \mathrm{H}_{\mathrm{dw}}+b \cdot{ }^{3} \mathrm{H}_{\mathrm{r}}=c \cdot{ }^{3} \mathrm{H}_{\mathrm{f}}$

where ${ }^{3} \mathrm{H}_{\mathrm{r}}$ is the tritium content of rainfall recharge water (groundwater aliquot $b$ ) and ${ }^{3} \mathrm{H}_{\mathrm{f}}$ is the tritium content of groundwater discharged (naturally or artificially) from the flysch aquifer sampled in DrA (groundwater aliquot $c$ ).

Subsequently, the groundwater aliquots $a$ and $b$ were used to estimate the theoretical $\delta^{18} \mathrm{O}$ of deep water recharge $\left(\delta^{18} \mathrm{O}_{\mathrm{dw}}\right)$ on the basis of Eq. (2):

$a \cdot \delta^{18} \mathrm{O}_{\mathrm{dw}}+b \cdot \delta^{18} \mathrm{O}_{\mathrm{r}}=c \cdot \delta^{18} \mathrm{O}_{\mathrm{f}}$

where $\delta^{18} \mathrm{O}_{\mathrm{r}}$ and $\delta^{18} \mathrm{O}_{\mathrm{f}}$ are the oxygen isotope values for rainfall recharge water and flysch groundwater, respectively.

In terms of annual volumes, aliquot $V_{\mathrm{dw}}$ corresponds to the volume of annual deep water inflow, while the aliquot $V_{\mathrm{r}}$ corresponds to volume of annual rainfall recharge and aliquot $V_{\mathrm{f}}$ corresponds to the annual volume of water discharged (naturally or artificially) from the flysch aquifer. In these terms, Eq. (3) can be written as:

$V_{\mathrm{dw}} \cdot \delta^{18} \mathrm{O}_{\mathrm{dw}}+V_{\mathrm{r}} \cdot \delta^{18} \mathrm{O}_{\mathrm{r}}=V_{\mathrm{f}} \cdot \delta^{18} \mathrm{O}_{\mathrm{f}}$

Considering a steady-state budget $\left(V_{\mathrm{IN}}=V_{\mathrm{OUT}}\right.$, so that $V_{\mathrm{r}}+V_{\mathrm{dw}}=V_{\mathrm{f}}$ ), Eq. (3) can be rewritten as:

$V_{\mathrm{dw}} \cdot \delta^{18} \mathrm{O}_{\mathrm{dw}}+V_{\mathrm{r}} \cdot \delta^{18} \mathrm{O}_{\mathrm{r}}=\left(V_{\mathrm{r}}+V_{\mathrm{dw}}\right) \cdot \delta^{18} \mathrm{O}_{\mathrm{f}}$

Finally, the volume of annual deep water inflow $\left(V_{\mathrm{dw}}\right)$ can, therefore, be calculated as:

$V_{\mathrm{dw}}=V_{\mathrm{r}} \cdot\left[\left(\delta^{18} \mathrm{O}_{\mathrm{f}}-\delta^{18} \mathrm{O}_{\mathrm{r}}\right) /\left(\delta^{18} \mathrm{O}_{\mathrm{dw}}-\delta^{18} \mathrm{O}_{\mathrm{f}}\right)\right]=V_{\mathrm{r}} \cdot I_{\mathrm{r}}$

where $I_{\mathrm{r}}$ is the relative $\delta^{18} \mathrm{O}$ isotopic ratio.

The calculation is affected by uncertainties related to the estimated annual rainfall recharge volume $V_{\mathrm{r}}$ (in the order of 20-25\% according to Fetter, 2001), and by uncertainties related to measured or calculated isotopic values (the latter assessed using the common error propagation methods reported in Taylor, 1997).

\section{Results}

\subsection{Groundwater monitoring}

The main groundwater recharge into the slope takes place in the autumn and spring when the effective rainfall, i.e., water surplus (Thornthwaite and Mather, 1957), is available. Similarly to the rainfall pattern, $\mathrm{GW}_{\mathrm{L}}$ show two peaks: one in November-December and another in April $\left(\mathrm{GW}_{\mathrm{L}}\right.$ patterns are reported in Fig. 3a). These peaks are normally followed by groundwater regression periods; the main one between May and October. In the crown area (P1), the groundwater response delay after rainfall events is in the order of a few hours up to a couple of days, while the $\mathrm{GW}_{\mathrm{L}}$ can increase by more than $5 \mathrm{~m}$. These $\mathrm{GW}_{\mathrm{L}}$ peaks then discharge completely within 5-10 days. The maximum seasonal amplitude is about $7 \mathrm{~m}$. The flysch rock mass in the crown is intensively fractured (P2) and behaves differently. $\mathrm{GW}_{\mathrm{L}}$ variations for each event are modulated or even absent (as the consequence of high hydraulic conductivity). However, during an intensive rainfall-recharge period, an increase of more than $10 \mathrm{~m}$ was detected. In the head zone, above the main sliding surface (P3), $\mathrm{GW}_{\mathrm{L}}$ are affected by the high-frequency pumping in WA; as a result, they are stabilised at about $29 \mathrm{~m}$ from the ground surface. In the deepest piezometers, which monitor deep multi-compartmented horizons (P4, P5: since the records are overlapping, only the second is represented in Fig. 3a), $\mathrm{GW}_{\mathrm{L}}$ are $20 \mathrm{~m}$ higher than the $\mathrm{GW}_{\mathrm{L}}$ observed inside the main landslide body (P3). Only the most intense precipitations (such as $150 \mathrm{~mm}$ on 10 June 2008) can influence the $\mathrm{GW}_{\mathrm{L}}$ record (total head increased by $1 \mathrm{~m}$ after 1 month) while seasonal peaks are modulated $(2-4 \mathrm{~m})$ and shifted by some months compared to the rainfall records.

Despite $\mathrm{GW}_{\mathrm{EC}}$ continuous monitoring only are available for the head zone, different trends can be observed (Fig. 4). Above the sliding surface (P3), a continuous decrease in $\mathrm{GW}_{\mathrm{EC}}$ is evident. Starting from $5450 \mu \mathrm{S} \mathrm{cm}^{-1}$, it fell to a final value of around $5100 \mu \mathrm{S} \mathrm{cm}^{-1}$ with a minimum of $4570 \mu \mathrm{S} \mathrm{cm}^{-1}$ on 22 October 2009 . This drop was the result of automatic pumping switching-on in WA and the consequent downflow of less mineralised water coming from the shallow part of the landslide body. A new equilibrium was reached only after 3 months $\left(5100 \mu \mathrm{S} \mathrm{cm}^{-1}\right)$. In summer 2011, due to continuous pumping, $\mathrm{GW}_{\mathrm{EC}}$ reached a new minimum value of $1247 \mu \mathrm{S} \mathrm{cm}^{-1}$. For the same time window, $\mathrm{GW}_{\mathrm{EC}}$ measured in $\mathrm{P} 4$ increased from 5500 to $5800 \mu \mathrm{S} \mathrm{cm}^{-1}$ with a smoothed peak of more than $6000 \mu \mathrm{S} \mathrm{cm}^{-1}$ in November 2010 . The latter was preceded by $300 \mathrm{~mm}$ of effective rainfall over 3 months, which provided slight $\mathrm{GW}_{\mathrm{L}}$ increases even in the deepest piezometers (P2). The discharge monitoring network started to collect data in 2006-2007 and was stopped in 2009 (WA) and so only the hydrologic year 20072008 is available for further comparison, when a total of $30000 \mathrm{~m}^{3}$ was drained from WA and $6000 \mathrm{~m}^{3}$ from DrA.

\subsection{Groundwater chemical analyses}

Groundwater salinity ranged between a minimum value of about $1.5 \mathrm{~g} \mathrm{l}^{-1}$ measured in the upper part of the slope (P1), to $6 \mathrm{gl}^{-1}$ measured in the lower part of the slope (DrA, sampling campaign F). According to Drever (1997), the latter can be classified as salt (brackish) water. These waters are enriched in $\mathrm{Na}^{+}$and $\mathrm{SO}_{4}^{2-}$ with substantial amounts of $\mathrm{HCO}_{3}^{-}$ (up to $1100 \mathrm{mgl}^{-1}$ ) and a significant content of $\mathrm{Cl}^{-}$(up to $787 \mathrm{mg}^{-1}$ in DrA). $p \mathrm{CO}_{2}$ ranged from about $6 \mathrm{kPa}(\mathrm{P} 4)$ to 


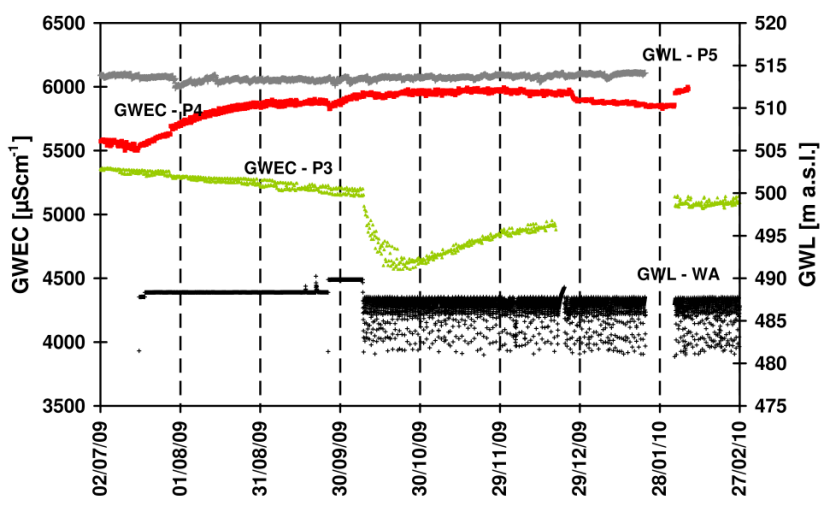

Fig. 4. Continuous groundwater electrical conductivity $\left(\mathrm{GW}_{\mathrm{EC}}\right)$ monitoring for piezometers P3 and P4 and groundwater level $\left(\mathrm{GW}_{\mathrm{L}}\right)$ monitoring in WA and P5.

$1.4 \mathrm{kPa}(\mathrm{DrA})$, while $\mathrm{pH}$ fluctuated around 7 (slightly acid in the upper part of the slope: 6.6-6.9 observed in P1).

The most mineralised water collected at $\mathrm{Ca}$ ' Lita during sampling campaign A (DrA) is reported in a Piper diagram together with other GW of NA (Fig. 5a). Whereas common shallow GW falls on the left side of the diamond, the $\mathrm{Ca}$ ' Lita sample plots in the right corner ( $\mathrm{Na}-\mathrm{SO}_{4} \mathrm{GW}$-type). This hydrofacies characterises all water sampled at $\mathrm{Ca}$ ' Lita (Fig. 5b), with P4 shifted downwards owing to the higher $\mathrm{HCO}_{3}^{-}$content.

Regarding the main ion contents (reported in Table 3), P3, P5 and DrB had the lower values for both ions $\mathrm{Na}^{+}$of about $500-600 \mathrm{mg} \mathrm{l}^{-1}$ and $\mathrm{SO}_{4}^{2-} 800-1000 \mathrm{mg} \mathrm{l}^{-1}$ ) while the other samples exceeded $800 \mathrm{mg}^{-1}$ and $1000 \mathrm{mg}^{-1}$, respectively. Marked discrepancies were detected in the $\mathrm{Cl}^{-}$contents. The head zone (P3, P4, P5) is characterised by lower levels of $\mathrm{Cl}^{-}$(less than $90 \mathrm{mgl}^{-1}$ ). The piezometers inserted inside the flysch rock masses (P1, P2) reached $300-400 \mathrm{mg}^{-1}$ with a maximum of $790 \mathrm{mg} \mathrm{l}^{-1}$ in DrA.

A comparison between sampling campaigns A, B and D was only possible for P1 and DrA. In 2009 (sampling campaign D) the $\mathrm{Cl}^{-}$contents were halved, while $\mathrm{Na}^{+}$and $\mathrm{SO}_{4}^{2-}$ slightly increased. The most pronounced increase involved DrA: in this case, $\mathrm{Na}^{+}$increased to about $1600 \mathrm{mg} \mathrm{l}^{-1}$ while $\mathrm{SO}_{4}^{2-}$ tripled (more than $3000 \mathrm{mg} \mathrm{l}^{-1}$ ). This fact is responsible of the upward displacement of the last DrA sample in the Piper diagram (Fig. 5b). Trace ion levels are available only for the last sampling campaign: $\mathrm{B}_{\text {tot }}$ concentrations reached $8.2 \mathrm{mg} \mathrm{l}^{-1}$ (DrA) and $6.4 \mathrm{mgl}^{-1}(\mathrm{P} 1) ; \mathrm{Sr}^{2+}$ varied from 6.8 (DrA) to 3.3 (P1) $\mathrm{mg} \mathrm{l}^{-1}$.

\subsection{Groundwater isotopic analyses}

The isotopic values $\delta^{18} \mathrm{O}$ and $\delta^{2} \mathrm{H}$ from groundwater samples collected in $\mathrm{Ca}$ ' Lita are summarised in Table 3 and are plotted in Fig. 6 together with the meteoric water line proposed by Longinelli and Selmo (2003). Several samples

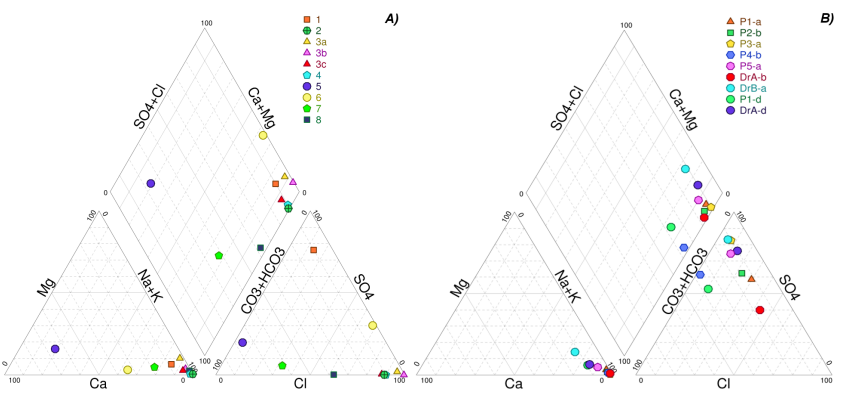

Fig. 5. Piper diagram. (a) Water sample DrA compared with common shallow groundwater (point: 5), other springs (point: 6 - Cervi, 2003; 7 - Venturelli et al., 2003), mud volcanoes (point: 3a, c - Martinelli et al., 1989), baths (point: 2, 4 - Boschetti et al., 2010) and hydrocarbon seep (point: 8) as described in Fig. 1a. (b) Ca' Lita water samples from the B and D campaigns.

from the landslide body (P4) or the lateral unstable flank (P2) were characterised by values of $\delta^{18} \mathrm{O}$ which varied significantly during the different sampling campaigns, ranging from $-8.51 \%$ to $-9.88 \%$ o. In one piezometer inside the landslide body (P5), $\delta^{18} \mathrm{O}$ did not change significantly over the seasons $\left(-9.13 \%\right.$; $-9.22 \%$ ). In P1 and DrA, $\delta^{18} \mathrm{O}$ values were significantly higher than rainfall water (up to $-1.61 \%$, in summer 2006). It was also noticed that as soon as the deep drainage mitigation system made of wells began to drain the landslide body, $\delta^{18} \mathrm{O}$ in DrA became more negative $\left(-6.93 \%\right.$ in summer 2010). In the $\delta^{18} \mathrm{O}-\delta^{2} \mathrm{H}$ plot (Fig. 6), samples from P2, P1 and DrA are aligned along a $\delta^{2} \mathrm{H}$ line which has a lower inclination that of the meteoric line. The closest point to the meteoric line is $\mathrm{P} 2$, while the most $\delta^{2} \mathrm{H}$ depleted points refer to samples from DrA (from $-31.04 \%$ o to $-53.54 \%$ ). Samples from other piezometers (P3, P4, P5) plot close to the local meteoric line. Following the approach of Gibson et al. (2005), the intersection between the alignment of samples from Ca' Lita and the meteoric water line can be considered as representative of $\delta^{18} \mathrm{O}-\delta^{2} \mathrm{H}$ rainfall water content. This gives $\delta^{18} \mathrm{O}$ of $-9.90 \%$, which is coincident to the lowest value measured in springs located in the Secchia river valley in the vicinity of Ca' Lita area (see springs labeled as Group 5 in Table 3, which are located in Fig. 1a). The lowest value of $\delta^{18} \mathrm{O}$ from $\mathrm{Ca}$ ' Lita samples falls on the meteoric water line and was obtained with one of the samples collected in $\mathrm{P} 2$, which indicates rapid infiltration in the vicinity of the sampling point. In the $d-\delta^{18} \mathrm{O}$ plot (Fig. 7), Ca' Lita samples are distributed along a line linking progressively more negative deuterium excess values. This alignment further evidences that a substantial differentiation exists between isotopic values of groundwater and of rainfall recharge water. Finally, the ${ }^{3} \mathrm{H}$ content measured in groundwater sampled from DrA during summer 2010 was 3.5 T.U., a value that is significantly lower than the ${ }^{3} \mathrm{H}$ of 9.8 T.U. considered as reference for rainfall recharge water. 


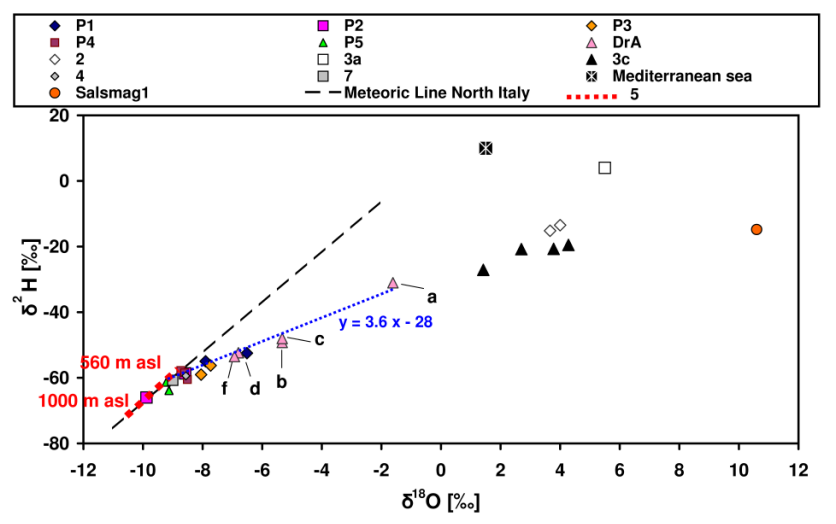

Fig. 6. $\delta^{18} \mathrm{O}-\delta^{2} \mathrm{H}$ diagram. DrA point sampling campaigns are reported. Point: 2, 4 (Boschetti et al., 2010) - baths; 3a (Conti et al., 2000), 3c (Capozzi and Picotti, 2010) - mud volcanoes; 7 (Venturelli et al., 2003) - spring; SalsMag1 (Boschetti et al., 2010) - oil well. Red dashed line was obtained from sampling group 5 - common shallow groundwater. Blue line represents the alignment of the $\delta^{2} \mathrm{H}$ depleted samples at $\mathrm{Ca}$ ' Lita. Black dashed line is the northern Italy meteoric line (Longinelli and Selmo, 2003).

\subsection{Leaching analyses}

The results of the leaching experiments are summarised in Table 4 . The time required to reach the final concentration was generally short for all the samples: at least $70 \%$ of the total chemical content was achieved within $10 \mathrm{~min}$, and $90 \%$ within $1 \mathrm{~h}$. Clearly, the $1 \mathrm{~h}$ samples are representative of the lixiviation interactions between soil and water. Once leached, all the $\mathrm{MOHa}$ and $\mathrm{MOHb}$ provided $\mathrm{Ca}-\mathrm{HCO}_{3}$ water with similar mineralisation (close to $200 \mu \mathrm{S} \mathrm{cm}^{-1}$ after $1 \mathrm{~h})$. Otherwise, appreciable differences were detected between MVR samples. In particular, an increase of mineralisation (up to $930 \mu \mathrm{S} \mathrm{cm}^{-1}$ while the furthest sample MVRb remained around $180 \mu \mathrm{S} \mathrm{cm}^{-1}$ ) was noticed in MVRa. Starting from the $\mathrm{Ca}-\mathrm{HCO}_{3}$ water of the former, the samples leached with MVRa soil collected along the main fault were enriched with $\mathrm{Na}^{+}$and $\mathrm{SO}_{4}^{2-}$ up to 160 and $175 \mathrm{mgl}^{-1}$, respectively. These results are only partially in agreement with the chemical characteristics of the water hosted in the deepest aquifer of Ca' Lita (DrA). In this case, unlike the water collected from DrA, only a few $\mathrm{mg}^{-1}$ of $\mathrm{Cl}^{-}$were detected during the leaching experiment.

\subsection{PHREEQC modelling}

The composition of the flysch rock mass (MOH) was established as $33.6 \%$ clay ( $25 \%$ smectites, $25 \%$ chlorites, $41 \%$ illites, $8 \%$ kaolinite), $55.8 \%$ quartz, $2 \%$ calcite, and $8.6 \%$ feldspar. MVR is mainly composed of clay (about $78 \%$ : $89 \%$ smectites, $8 \%$ kaolinite, and some traces of illites) together with $7.8 \%$ quartz, $13.3 \%$ calcite and $1.2 \%$ feldspar.

In the PHREEQC modelling, two different scenarios were tested according to the state of the hydrogeological system:
Table 4. Leaching results for the 4 soil samples collected. Chemical analyses for the $1 \mathrm{~h}$ samples are also reported in $\mathrm{mg}^{-1}$.

\begin{tabular}{|c|c|c|c|c|c|c|c|c|c|}
\hline \multirow[b]{2}{*}{ Soil sample } & \multicolumn{9}{|c|}{ Electrical conductivity $-25^{\circ} \mathrm{C}\left(\mu \mathrm{S} \mathrm{cm}^{-1}\right)$} \\
\hline & $30 \mathrm{~s}$ & $1 \mathrm{~min}$ & $2 \min$ & $5 \mathrm{~min}$ & $10 \mathrm{~min}$ & $30 \mathrm{~min}$ & $1 \mathrm{~h}$ & $5 \mathrm{~h}$ & $10 \mathrm{~h}$ \\
\hline $\mathrm{MOHa}$ & 68 & 106 & 133 & 157 & 193 & 196 & 206 & 222 & 228 \\
\hline MVRa & 460 & 615 & 694 & 817 & 924 & 855 & 861 & 754 & 928 \\
\hline $\mathrm{MOHb}$ & 78 & 107 & 135 & 192 & 198 & 205 & 244 & 249 & 251 \\
\hline \multirow[t]{2}{*}{ MVRb } & 81 & 96 & 112 & 123 & 140 & 148 & 179 & 194 & 199 \\
\hline & \multicolumn{9}{|c|}{ Chemical data at $1 \mathrm{~h}\left(\mathrm{mg} \mathrm{l}^{-1}\right)$} \\
\hline Soil sample & & $\mathrm{a}^{+}$ & $\mathrm{Mg}^{2+}$ & $\mathrm{Ca}^{2+}$ & $\mathrm{K}^{+}$ & $\mathrm{SO}_{4}^{2-}$ & $\mathrm{Cl}^{-}$ & & $\mathrm{CO}_{3}^{-}$ \\
\hline MOHa & & 40 & 2 & 5 & 1 & 12 & 0 & & 113 \\
\hline MVRa & & 160 & 4 & 8 & 3 & 175 & 5 & & 210 \\
\hline $\mathrm{MOHb}$ & & 25 & 3 & 20 & 2 & 16 & 0 & & 120 \\
\hline MVRb & & 10 & 2 & 18 & 1 & 10 & 0 & & 107 \\
\hline
\end{tabular}

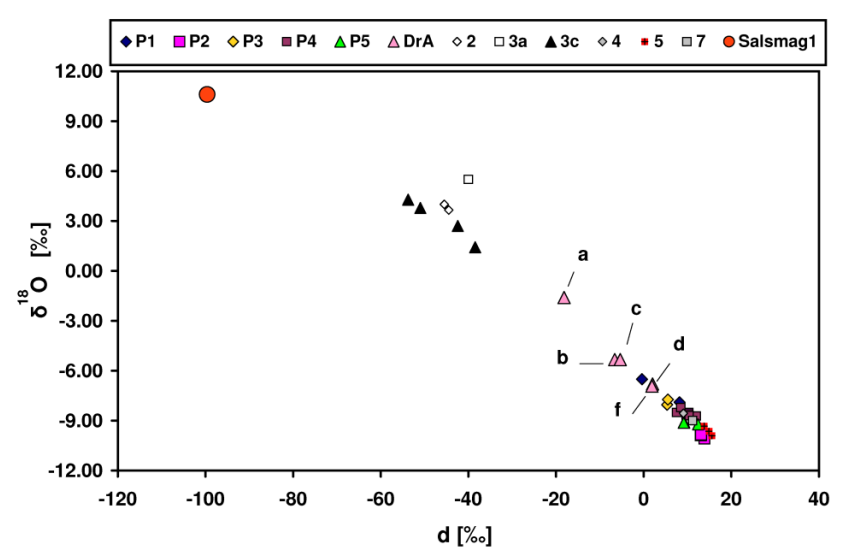

Fig. 7. $d-\delta^{18} \mathrm{O}$ diagram. DrA point sampling campaigns are reported. Point: 2, 4 (Boschetti et al., 2010) - baths; 3a (Conti et al., 2000), 3c (Capozzi and Picotti, 2010) - mud volcanoes; 7 (Venturelli et al., 2003) - spring; SalsMag1 (Boschetti et al., 2010) - oil well.

in the first, it was considered as closed to the surface $\left(p \mathrm{CO}_{2}\right.$ reached values of $2.5 \mathrm{kPa}$ and $3 \mathrm{kPa}$, respectively), while in the second a fixed partial pressure of $\mathrm{CO}_{2}$ was guaranteed ( $p \mathrm{CO}_{2}$ equal to $0.03 \mathrm{kPa}$ ). In both cases, some ions showed discrepancies even with the results obtained from the leaching experiment. $\mathrm{Mg}^{2+}$ was not present in the final solution $\left(<0.1 \mathrm{mg} \mathrm{l}^{-1}\right)$ while $\mathrm{Ca}^{2+}$ was assessed as around 2$4 \mathrm{mgl}^{-1}$. $\mathrm{Na}^{+}$content was increased through albite dissolution, reaching $100 \mathrm{mg} \mathrm{l}^{-1}$ (closed system) and some thousands in the second case. Regarding anion contents, only $\mathrm{HCO}_{3}^{-}$(more than $100 \mathrm{mg}^{-1}$ ) could be produced by these assemblages of minerals while no $\mathrm{SO}_{4}^{2-}$ was detected.

\section{Discussion}

\subsection{Origin of groundwater and deep water inflow}

Results suggest the existence of a complex hydrogeological system comprising overlapping aquifers characterised by the presence of $\mathrm{Na}-\mathrm{SO}_{4} \mathrm{GW}$. In the landslide body (head zone), 
the aquifer hosted above the main sliding surface (P3) exhibits an unconfined behaviour (Fig. 2b). Its response to rainfall events is fast. The same patterns can be noticed in $\mathrm{GW}_{\mathrm{EC}}$ : values range between 1000 to $5000 \mu \mathrm{S} \mathrm{cm}^{-1}$.

Below the sliding surface ( $\mathrm{P} 4$ and P5), in the thick deformation band made up of disarranged flysch, the same aquifer becomes semi-confined (or multi-compartmented). $\mathrm{GW}_{\mathrm{L}}$ have no direct relationships with rainfall as only modulated (changes less than $5 \mathrm{~m}$ ) seasonal variations are observed. $\mathrm{P} 4$ had higher $\mathrm{GW}_{\mathrm{EC}}$ values and ion contents, together with less depleted values of $\delta^{18} \mathrm{O}$ (between $-8.51 \%$ o and $-8.73 \%$ o compared to $-9.22 \%$ observed for P5).

However, in both cases the chemical imprints are quite similar and characterised by low $\mathrm{Cl}^{-}$contents (less than $88 \mathrm{mg} \mathrm{l}^{-1}$ ). All the water samples taken lie on the local meteoric isotopic line, and the most depleted values of $\delta^{18} \mathrm{O}$ (close to $-9.22 \%$ ) can be assumed to be strongly linked to infiltration processes. The aquifer hosted in the undisturbed flysch (P1 and DrA) and in the side crown (P2) behaves differently. Depending on the denser and more persistent fracturing pattern characterising the crown zone, $\mathrm{GW}_{\mathrm{L}}$ variations in $\mathrm{P} 1$ are higher than those detected in P2. However, both piezometers are characterised by water depleted in $\delta^{2} \mathrm{H}$ together with high contents of $\mathrm{Cl}^{-}\left(300-400 \mathrm{mg} \mathrm{l}^{-1}\right)$. The latter reaches about $800 \mathrm{mg}^{-1}$ at the bottom of the aquifer (DrA). Discharged water is the most mineralised ( $\mathrm{GW}_{\mathrm{EC}}$ up to $9500 \mu \mathrm{S} \mathrm{cm}^{-1}$ ).

A sharp decline in chemical parameters occurred during November 2009: $\mathrm{GW}_{\mathrm{EC}}$ in the landslide body repositioned at about $1500 \mu \mathrm{S} \mathrm{cm}^{-1}$ (P3). Due to the continuous pumping in WA, the unconfined aquifer hosted in the head zone was progressively renewed by the inflow of more fresh and less mineralised water from the upper landslide body. This presence was confirmed by Ronchetti et al. (2009) after conductivity loggings in P1: the authors detected a rapid increase of $\mathrm{GW}_{\mathrm{EC}}$ with depth (stabilised at about $4000 \mu \mathrm{S} \mathrm{cm}^{-1}$ at $20 \mathrm{~m}$ below $\mathrm{GW}_{\mathrm{L}}$ ). The undisturbed flysch aquifer suffered by the hydrological changes of the head zone: in sampling points P1 and $\operatorname{DrA}, \mathrm{Cl}^{-}$contents were halved.

A change in hydrochemical characteristics following continuous pumping in WA was also observed in the $\delta^{18} \mathrm{O}$ record. In DrA, $\delta^{18} \mathrm{O}$ decreased from $-1.61 \%$ in July 2006, to $-5.33 \%$ in July 2007 up to $-6.93 \%$ in August 2010 . This can be interpreted as the result of an increased contribution of lighter rain water infiltrating into bedrock from the upper landslide body, thus, producing a mixture of rainfall recharge water and deep groundwater. As previously reported, a $\delta^{18} \mathrm{O}=-9.90 \%$, can be considered as representative rainfall recharge isotopic content (point of intersection between the alignment of samples from $\mathrm{Ca}^{\prime}$ Lita and the meteoric water line). On the other hand, an indicative value for the mean annual $\delta^{18} \mathrm{O}$ of deep groundwater of about $+3 \%$ o can be estimated by solving Eq. (2) described in Sect. 3.7. An estimated value of $\delta^{18} \mathrm{O}$ of about $+3 \%$ o for deep water inflow is consistent with $\delta^{18} \mathrm{O}$ values measured in mud volcanoes located $15 \mathrm{~km}$ to the north (points no. 3a, b in Fig. 1a)
(Martinelli et al., 1989) as well as in other springs flowing out of TU flysch formations (i.e., Well SalsMag1 in Boschetti et al., 2010) or from LU-TU formations in the middle-frontal part of the Apennine chain (i.e., Regnano site point $3 \mathrm{c}$ in Fig. 1a; Capozzi and Picotti, 2010).

The hypothesis that the isotopic differentiation between groundwater sampled in Ca' Lita and rainfall recharge water is likely to be due to the inflow of a certain aliquot of deep water, is corroborated by the consideration that the influence of evaporative processes on $\delta^{2} \mathrm{H}$ depletion and enhancement of $\delta^{18} \mathrm{O}$ values can most likely be excluded on the basis of a number of reasons. First, the slope of the regression line linking groundwater samples in the $\delta^{18} \mathrm{O}-\delta^{2} \mathrm{H}$ plot is 3.6 (see Fig. 6). This is lower than those reported by Celico (1986) and Kendall and Caldwell (1998) in similar environmental contexts (3.9 to 6.8 with humidity of $0 \%$ to $95 \%$, respectively). Furthermore, a distribution of $\mathrm{Ca}$ ' Lita samples along a line linking progressively more negative deuterium excess values is evident in the $d-\delta^{18} \mathrm{O}$ plot (Fig. 7). Evaporation only occurs if the groundwater table is close to the surface (Mazor, 1997; Kendall and McDonnel, 1998) whereas the $\mathrm{GW}_{\mathrm{L}}$ depth in $\mathrm{Ca}$ ' Lita ranges from -5 to $-30 \mathrm{~m}$ and groundwater temperature $\mathrm{GW}_{\mathrm{T}}$ is generally stable at around $13.5^{\circ} \mathrm{C}$ throughout the seasons, showing no influence of atmospheric temperature variations. It should be considered that the most depleted $\delta^{2} \mathrm{H}$ and the higher $\delta^{18} \mathrm{O}$ values refer to DrA, which collects water at depths greater than $50 \mathrm{~m}$, making evaporation very improbable. In addition to that, DrA conductivity and $\delta^{18} \mathrm{O}$ values for three different sampling campaigns (see B-D-F in Table 3) are available. As reported by Gonfiantini et al. (1974) and Simpson et al. (1987) evaporation process should lead to positive correlation between salinity and $\delta^{18} \mathrm{O}$ in the residual water. On the contrary, this is not occurring in DrA, where samples showing the most enriched values of $\delta^{18} \mathrm{O}$ are characterised by lower conductivities. For these reasons, isotopic values in DrA can be considered as reference values for groundwater in the flysch aquifer underlying the landslide. As a consequence, the ${ }^{3} \mathrm{H}$ content of 3.5 T.U. measured in groundwater sampled from DrA during summer 2010, can be used as the reference value of ${ }^{3} \mathrm{H}$ for the flysch aquifer. This value, it should be recalled, is significantly lower than the ${ }^{3} \mathrm{H}$ value of 9.8 T.U. which has been considered as reference for rainfall recharge water.

Other evidence corroborates the hypothesis of a mixing taking place between deep water inflow and rainfall-recharge water inside the bedrock underneath the landslide. The content of $\mathrm{B}_{\text {tot }}$ and $\mathrm{Sr}^{2+}$ in DrA is three orders of magnitude larger than the values normally found in shallow springs of NA (a few $\mu \mathrm{g} 1^{-1}$ as reported by Duchi et al., 2005; Toscani et al., 2001). Considering the data reported in Sect. 2 and Mather and Porteous (2001), the long-term interaction between water and host rocks (such as flysch and/or evaporites) cannot in itself justify the measured $B_{\text {tot }}$ values. Mud volcanoes and oilfield waters are consistent with the $B_{\text {tot }}$ contents detected at $\mathrm{Ca}^{\prime}$ Lita, while $\mathrm{Sr}^{2+}$ is much higher than 
Table 5. Relevant data and results of isotopic groundwater balance at the landslide slope scale. Precision of measured values is that of the analytical determination methods. Uncertainties in calculated values are assessed using error propagation methods presented by Taylor (1997). Rainfall recharge volume $\left(V_{\mathrm{r}}\right)$ is calculated with the Thornthwaite and Mather (1957) formula by using infiltration coefficient $\left(I_{\mathrm{c}}\right)$ ranging from 0.4 to 0.7 . The uncertainty related to $V_{\mathrm{r}}$ is considered equal to $\pm 20-25 \%$ by Fetter (2001), mostly due to the quality of the original rainfall and temperature datasets. As the quality level of the adopted ARPA dataset could not be assessed specifically in this study, an indicative value of $\pm 20 \%$ is given.

\begin{tabular}{|c|c|c|c|}
\hline Data & Source & Value & Precision \\
\hline$V_{\mathrm{r}}$ - annual rainfall recharge volume $\left(I_{\mathrm{c}} 0.4\right.$ to 0.7$)$ & Calculated & 27000 to $48000 \mathrm{~m}^{3} \mathrm{yr}^{-1}$ & $\pm 20 \%$ \\
\hline$\delta^{18} \mathrm{O}_{\mathrm{r}}$ - rainfall recharge water (aliquot $b$ ) & Defined on $\delta^{18} \mathrm{O}-\delta^{2} \mathrm{H}$ plot & $-9.90 \%$ & $\pm 0.05 \%$ \\
\hline$\delta^{18} \mathrm{O}_{\mathrm{f}}-$ flysch aquifer discharge water (aliquot $c$ ) & Measured in DrA & $-1.61 \%$ & $\pm 0.05 \%$ \\
\hline${ }^{3} \mathrm{H}_{b}$ - rainfall recharge water (aliquot $b$ ) & From ARPA data & 9.8 T.U. & \pm 0.2 T.U. \\
\hline${ }^{3} \mathrm{H}_{\mathrm{c}}$ - flysch aquifer discharge water (aliquot $c$ ) & Measured in DrA & 3.5 T.U. & \pm 0.2 T.U. \\
\hline${ }^{3} \mathrm{H}_{\mathrm{a}}$ - deep water inflow (aliquot $a$ ) & Assumed & 0 T.U. & \\
\hline Results & Source & Calculated value & Uncertainty \\
\hline$b$ aliquot (rainfall recharge water aliquot) & Equation (1) & 0.36 & \pm 0.02 \\
\hline$a$ aliquot (deep water inflow aliquot) & Equation (1) & 0.64 & \pm 0.02 \\
\hline$\delta^{18} \mathrm{O}_{\mathrm{dw}}$ aliquot $a$ (deep water inflow aliquot) & Equation (2) & $+3.07 \%$ & $\pm 0.31 \%$ \\
\hline$I_{\mathrm{r}}-$ relative $\delta^{18} \mathrm{O}$ isotopic ratio & Equation (5) & 1.80 & \pm 0.16 \\
\hline \multirow{2}{*}{$V_{\mathrm{dw}}-$ annual deep water inflow volume } & Equation (5) & 49000 to & \pm 16600 to \\
\hline & & $85700 \mathrm{~m}^{3} \mathrm{yr}^{-1}$ & $28000 \mathrm{~m}^{3} \mathrm{yr}^{-1}$ \\
\hline
\end{tabular}

expected. It should be noted that, unlike $\mathrm{Sr}^{2+}, \mathrm{B}$ behaves in a more conservative way and can hardly precipitate from the solution (Grew and Anovitz, 1996; Walker, 1975). Even admitting the presence of adsorption processes such as those detected in marine environments by Couch (1971), B would have been incorporated in clays' tetrahedral sheet structures at a very low rates (Keren and Mezuman, 1981) and it cannot be re-dissolved at the $\mathrm{Ca}$ ' Lita site temperatures. Therefore, $\mathrm{B}_{\text {tot }}$ contents linked to the deep water inflows could even be larger than those measured.

If mud volcanoes and oil field waters are plotted in a $\delta^{18} \mathrm{O}$ $\mathrm{Cl}^{-}$graph (Conti et al., 2000), they represent one of the endmembers of a hypothetical mixing line connecting them with shallow GW. GW from Ca' Lita falls on this line (Fig. 8). At the same time, the $\delta^{18} \mathrm{O}-\mathrm{B}_{\text {tot }}$ graph (Fig. 9) makes it possible to separate these two components. Ca' Lita water is completely left-shifted from the mud volcano points, which are polluted by an extra source of B contained in the connate waters of QM. This suggests a purely foredeep origin (oilfield waters) for the Ca' Lita GW. Leaching experiments on soil samples strengthen this conclusion. In particular, water which interacted with MVRa samples collected at Ca' Lita became more enriched in $\mathrm{Na}^{+}$and $\mathrm{SO}_{4}^{2-}$ than MVRb leading to the supposition that these clayey outcrops were impregnated with deep water. The interactions with $\mathrm{MOH}$ samples (MOHa and $\mathrm{MOHb}$ ) did not produce any changes in water chemistry and ion contents. A simple chemical equilibrium analysis was conducted coupling the mineralogical compositions of the soil samples using PHREEQC software. The investigation underlined that, even at equilibrium, the observed levels of $\mathrm{Ca}^{2+}$ and $\mathrm{SO}_{4}^{2-}$ cannot be reached. Moreover, there are no local mineralogical phases that could provide $\mathrm{Cl}^{-}$.

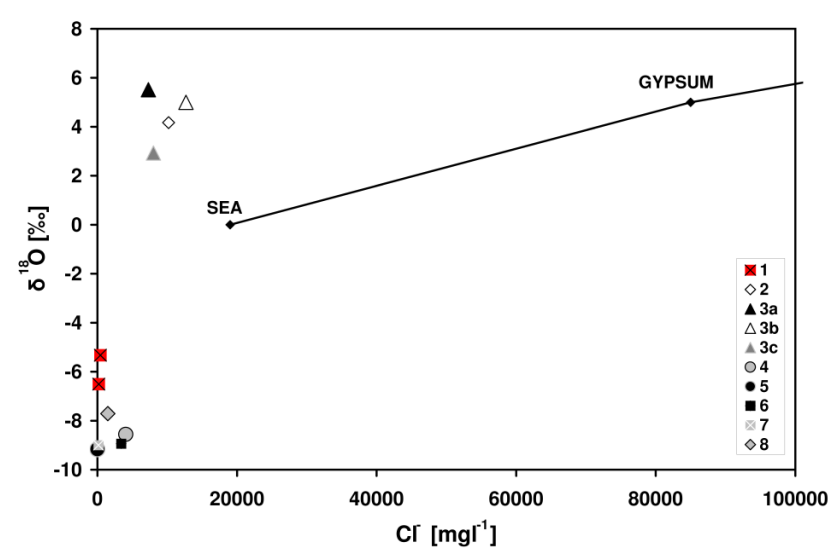

Fig. 8. $\mathrm{Cl}^{-}-\delta^{18} \mathrm{O}$ diagram. Point: 2,4 (Boschetti et al., 2010) baths; 3 a (Conti et al., 2000), 3b and 3c (Capozzi and Picotti, 2010) - mud volcanoes; 5 - common shallow groundwater; 6 (Cervi, 2003), 7 (Venturelli et al., 2003) - springs; 8 - hydrocarbon seep. Black line: evaporation line from seawater.

\subsection{Estimated aliquot and volume of deep water inflow in the landslide}

The aliquot and the annual volume of deep water inflow at the landslide slope was estimated by using the isotopic groundwater balance approach described in Sect. 3.7. Table 5 summarises relevant data and results. The rainfall recharge area corresponds to about $340000 \mathrm{~m}^{2}$, which is approximately the extent of the slope including stable flysch at the crown, at the sides and the landslide area, thus, excluding only the areas in which impermeable clayshales outcrop. 


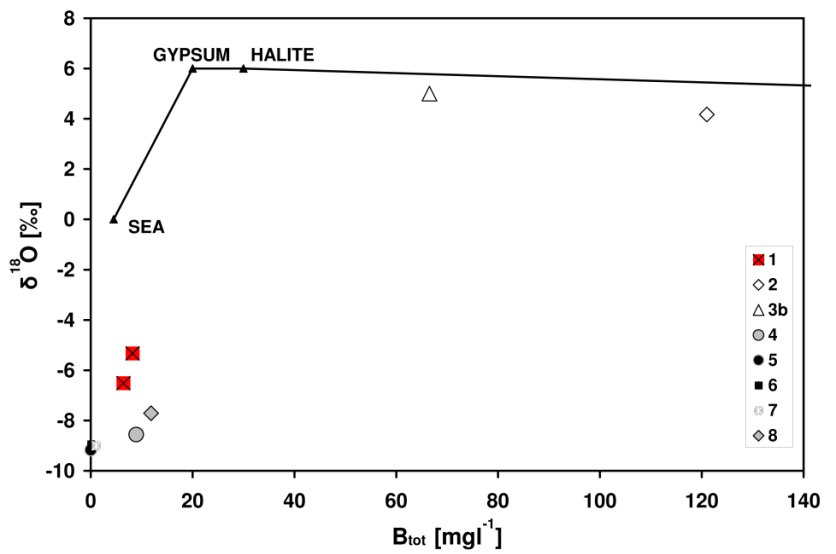

Fig. 9. $\mathrm{B}_{\mathrm{tot}}-\delta^{18} \mathrm{O}$ diagram. Point: 2,4 (Boschetti et al., 2010) baths; $3 \mathrm{~b}$ - mud volcanoes; 5 - common shallow groundwater; 6 (Cervi, 2003), 7 (Venturelli et al., 2003) - springs; 8 - hydrocarbon seep. Black line: evaporation line from seawater.

The mean annual rainfall recharge was estimated using the Thornthwaite and Mather (1957) formula using a $40 \mathrm{yr}$ long records of rainfall and temperature. A annual water surplus of $200 \mathrm{~mm} \mathrm{yr}^{-1}$ was calculated, which is concentrated between December and April (Table 2). Table 2 compares $\mathrm{GW}_{\mathrm{L}}$ variations and the total and effective rainfall recharge calculated for each hydrological year. A direct relation can be observed. The 2006-2007 hydrological year was characterised by the lowest recharge value and consequent minimum $\mathrm{GW}_{\mathrm{L}}$ in each piezometer. Conversely, 2009-2010 was very wet and the maximum $\mathrm{GW}_{\mathrm{L}}$ was recorded at all points. Considering the annual water surplus and recharge area, the mean annual volume of rainfall recharge in the slope $\left(V_{\mathrm{r}}\right)$ was estimated to be in the range of 27000 to $48000 \mathrm{~m}^{3}$, depending on the infiltration coefficients used $\left(I_{\mathrm{c}}=0.4\right.$ to 0.7 , which is the range of values flysch rocks in the northern Apennines reported by Civita, 2005). The uncertainties related to rainfall recharge volume $\left(V_{\mathrm{r}}\right)$ estimates are considered as large as $20-25 \%$ by Fetter (2001), mostly due to the quality of the original rainfall and temperature datasets. As the quality level of the adopted ARPA rainfall dataset (ARPA, 2010) could not be assessed specifically in this study, an indicative value of $20 \%$ can be assumed.

Equation (1) allows the aliquot of rainfall recharge water (aliquot $b)$ to be estimated in $36 \%(0.36 \pm 0.02)$ and the aliquot of deep water inflow (aliquot a) to be estimated in $64 \%(0.64 \pm 0.02)$. By considering a steady state (Eqs. 3 to 5 ) in which the total annual recharge of groundwater (given by rainfall recharge water and deep water inflow) equals annual discharge from the slope (assumed to have the isotopic characteristics of water hosted in the flysch, and sampled in DrA) (Fig. 10), the annual deep water inflow aliquot in terms of volume $\left(V_{\mathrm{dw}}\right)$ can be estimated as 49000 to $85700 \mathrm{~m}^{3}$. In other words, the deep water annual inflow $V_{\mathrm{dw}}$ can be estimated to be about $1.80 \pm 0.16$ times larger than the rainfall



Fig. 10. Reservoir-concept model of the slope. Water volumes $\left(V_{\mathrm{r}}\right.$ : annual rainfall volume; $V_{\mathrm{dw}}$ : annual deep water volume inflow; $V_{\mathrm{f}}$ : annual volume of water hosted inside the flysch; $V_{\text {OUT }}$ : annual water outflow volume) and their corresponding isotopic signals.

and it represents a constant influx (in the order of 1.5 to $2.71 \mathrm{~s}^{-1}$ ) that can be considered an influential factor for the long-term groundwater level fluctuations.

\section{Conclusions}

This research showed that in Ca' Lita landslide a significant aliquot of deep water inflow has to be considered in conjunction with rainfall recharge in order to interpret the chemical and isotopic composition in the landslide and in the surrounding slopes. Moreover, it demonstrates that the hydrogeological basin of the landslide is significantly different from the hydrological one, as it includes deep sectors of the slope. This conclusion is supported by evidences coming from multiple observations, including the anomalous chemical and isotopic composition of sampled water, the results from mineralogical analyses, the hydrochemical modelling using PHREEQC and the leaching tests. The chemical and isotopic fingerprint of deep water in the landslide slope points to oilfield water hosted at large depths in the northern Apennine chain. Several authors have documented the presence of this type of deep water in many locations in the Apennines and have generally ascribed their uprising motion as related to the presence of tectonic lineaments. The $\mathrm{Ca}$ ' Lita landslide is characterised by the presence of a regional fault line that crosses the landslide area and which can be considered as the preferential flow path for deep water uprise. Deep water is then diffused in the slope via a network of discontinuities affecting both bedrock and landslide body.

Therefore, this study highlights how deep fluids can condition geomorphic processes such as favouring slope instability. Actually, the results obtained in Ca' Lita indicate that the amount of groundwater recharge due to deep water inflow might be larger than the amount due to rainfall recharge. 
Thus, correlations of instability events to rainfall only, would be erroneous and misleading. Furthermore, this deep water contribution has to be accounted for the design of mitigation works, such as for instance deep drainage systems. Monitoring data from the weirs at the drainage system outlets registered around $6000 \mathrm{~m}^{3} \mathrm{yr}^{-1}$ of discharge from DrA, and around $30000 \mathrm{~m}^{3} \mathrm{yr}^{-1}$ from WA, a value that is within the range of the estimated deep water annual inflow if uncertainties in groundwater balance are considered.

In conclusion, the paper demonstrates the applicability of hydrological and hydrochemical analyses for quantifying the relative contribution of different sources of groundwater in slope-scale water budgets. This type of approach can be very useful in the study of large deep seated landslides, in which heterogeneity of constituting materials is high, and in which the hydrogeological basin can differ significantly from the hydrological one. A good understanding of the hydrological limits is essential when calculating representative hydrological budgets and if long-term stability modelling has to be carried out by interpreting the processes governing groundwater levels and their fluctuations in time and by evaluating the effectiveness of deep drainage mitigation systems. Hydrochemistry should, therefore, be considered as a valuable investigation method to assess the groundwater flow patterns in deep-seated landslide.

Acknowledgements. A large amount of data have been made available by Emilia-Romagna Region, Servizio Tecnico dei bacini degli affluenti del Po, Reggio Emilia, in the frame of a bilateral agreement. The authors would like to thank the Associate Editor M. Mikos and the two reviewers M. Giudici and M. Brencic as their valuable and constructive remarks greatly improved the early version of the manuscript. The manuscript is dedicated to the memory of Maurizio Pellegrini, head of Engineering Geology Group of the University of Modena and Reggio E., which continuously provided valuable suggestions on the study of large landslides in northern Apennines.

Edited by: M. Mikos

\section{References}

ARPA - Regional Agency for Environmental Protection in the Emilia-Romagna Region: Caratterizzazione geochimica dell' acquifero superficiale e definizione del suo stato di contaminazione, in: Progetto di Fattibilita per la Bonifica dell'Acquifero Superficiale dell'Area del Distretto Ceramico di Modena e Reggio Emilia, Bologna, 122 pp., 2009.

ARPA - Regional Agency for Environmental Protection in the Emilia-Romagna Region: precipitation database, available at: http://www.arpa.emr.it (last access: 9 May 2012), 2010.

Baraldi, S.: Caratterizzazione idrogeologica, idrochimica e radiometrica di alcuni corpi di frana dell'Appennino Emiliano, Casi di studio: Vedriano, Ca' Lita e Silla, Il Geologo dell'Emilia Romagna, 18, 19-36, 2008.
Bertolini, G. and Gorgoni, C.: La lavina di Roncovetro (Vedriano, Comune di Canossa, Provincia di Reggio Emilia), Quad. Geolog. Appl., 8, 1-21, 2001.

Bettelli, G. and Vannucchi, P.: Structural style of offscraped Ligurian oceanic sequences of the northern Apennines: new hypothesis concerning the development of the melange block-in-matrix fabric, J. Struct. Geol., 25, 371-388, 2003.

Bettelli, G., Panini, F., and Capitani, M.: Carta geologico-strutturale dell'Appennino emiliano sudorientale, Bologna, Atti Terzo Seminario sulla Cartografia Geologica Bologna, Stampa Labanti, 2002.

Boccaletti, M., Elter, P., and Guazzone, G.: Plate tectonics models for the development of the Western Alps and northern Apennines, Nature, 234, 108-111, 1971.

Bogaard, T., Guglielmi, Y., Marc, V., Emblanch, C., Bertrand, C., and Mudry, J.: Hydrogeochemistry in landslide research: a review, B. Soc. Geol. Fr., 178, 113-126, 2007.

Bonini, M.: Interrelations of mud volcanism, fluid venting, and thrust-anticline folding: examples from the external northern Apennines (Emilia-Romagna, Italy), J. Geophys. Res., 112, 121, 2007.

Bonzanigo, L., Eberhardt, E., and Loew, S.: Hydromechanical factors controlling the creeping Campo Vallemaggia landslide, in: Proceeding of Landslides-Causes, Impacts and Countermeasures, Davos, Switzerland, 13-22, 2001.

Borgatti, L., Corsini, A., Barbieri, M., Sartini, G., Truffelli, G., Caputo, G., and Puglisi, C.: Large reactivated landslides in weak rock masses: a case study from the Northern Apennines (Italy), Landslides, 3, 115-124, 2006.

Borgatti, L., Corsini, A., Marcato, G., Ronchetti F., and Zabuski, L.: Appraise the structural mitigation of landslide risk via numerical modelling: a case study from the northern Apennines (Italy), Georisk, 2, 141-160, 2008.

Boschetti, T., Toscani, L., Shouakar-Stash, O., Iacumin, P., Venturelli, G., Mucchino, C., and Frape, S. K.: Salt waters of the northern Apennine Foredeep basin (Italy): origin and evolution, Aquat. Geochem., 17, 71-108, 2010.

Buttinelli, M., Procesi, M., Cantucci, B., Quattrocchi, F., and Boschi, E.: The geo-database of caprock quality and deep saline aquifers distribution for geological storage of $\mathrm{CO}_{2}$ in Italy, Energy, 36, 2968-2983, 2011.

Capozzi, R. and Picotti, V.: Fluid migration and origin of a mud volcano in the northern Apennines (Italy): role of deeply rooted normal fault, Terra Nova, 14, 363-370, 2002.

Capozzi, R. and Picotti, V.: Spontaneous fluid emission in the northern Apennines: geochemistry, structures, and implications for the petroleum system, Geol. Soc. Spec. Publ., 348, 115-135, 2010.

Cappa, F., Guglielmi, Y., Soukatchoff, V. M., Mudry, J., Bertrand, C., and Charmoille, A.: Hydromechanical modeling of a large moving rock slope inferred from slope levelling coupled to spring long-term hydrochemical monitoring: example of the La Clapiere landslide (Southern Alps, France), J. Hydrol., 291, 6790, 2004.

Celico, P.: Prospezioni idrogeologiche, Vol. I. Pitagora, Napoli, Italy, 735 pp., 1986.

Cervi, F.: Idrologia chimica, isotopica e radiometrica dell'alta Val di Secchia (Chemical, isotopical and radiometrical hydrology of the Upper Secchia Valley), BSc thesis, Universita di Modena e Reggio Emilia, Italy, 94 pp., 2003. 
Chiesi, M., De Waele, J., and Forti, P.: Origin and evolution of a salty-gypsum/anhydrite karst spring: the case of Poiano (northern Apennines, Italy), Hydrogeol. J., 18, 1111-1124, 2010.

Ciancabilla, N., Borgia, G. C., Bruni, R., Ciancabilla, F., Palmieri, S., and Vicari, L.: Le sorgenti sulfuree dell'alta valle del Reno (Appennino bolognese): nuovi elementi per approfondire la genesi dei movimenti gravitativi profondi nei terreni argillitici caoticizzati dell' Appennino Tosco-Emiliano, Il Geologo dell'EmiliaRomagna, 18, 5-14, 2004.

Civita, M.: Idrogeologia applicata e ambientale, Casa Editrice Ambrosiana, Milano, 794 pp., 2005.

Colombetti, F. and Nicolodi, F.: La sorgente sulfurea della Frana di Farneta nella valle del Torrente Dolo (Prov. Di Modena) (The sulphurous spring of Farneta's Landslide (Montefiorino, Modena District)), Acta Naturalia de l'Ateneo Parmense, 34, 5-18, 1998.

Conti, A., Sacchi, E., Chiarle, M., Martinelli, G., and Zuppi, G. M.: Geochemistry of the formation waters in the Po plain (northern Italy), Appl. Geochem., 15, 51-65, 2000.

Corsini, A., Borgatti, L., Caputo, G., De Simone, N., Sartini, G., and Truffelli, G.: Investigation and monitoring in support of the structural mitigation of large slow moving landslides: an example from Ca' Lita (Northern Apennines, Reggio Emilia, Italy), Nat. Hazards Earth Syst. Sci., 6, 55-61, doi:10.5194/nhess-6-552006, 2006.

Corsini, A., Borgatti, L., Cervi, F., Dahne, A., Ronchetti, F., and Sterzai, P.: Estimating mass-wasting processes in active earth slides - earth flows with time-series of High-Resolution DEMs from photogrammetry and airborne LiDAR, Nat. Hazards Earth Syst. Sci., 9, 433-439, doi:10.5194/nhess-9-433-2009, 2009.

Couch, E. L.: Calculation of palaeosalinities from boron and clay mineral data, Bull. Am. Assoc. Pet. Geol., 55, 1829-1837, 1971.

Cremaschi, F.: Evidenze isotopiche, chimico-fisiche e piezometriche della circolazione idrica sotterranea in acquiferi fratturati e porosi dell'Appennino settentrionale (Monte Modino, Alta Val Secchia) (Isotopical, chemical and piezometric evidences of groundwater circulation through fractured and porous aquifers of the northern Apennines), BSc Thesis, Universita di Modena e Reggio Emilia, Italy, 115 pp., 2008.

Cruden, D. M. and Varnes, D. J.: Landslides types and processes, in: Landslides: Investigation and Mitigation, Special Report, edited by: Turner, A. K. and Schuster, R. L., Transportation Research Board, National Academy Press, Washington DC, 247, 36-75, 1996.

Dadomo, A. and Martinelli, G.: Aspetti di Idrologia Isotopica in Emilia-Romagna. In: Giornata Mondiale dell'Acqua. Acqua e copertura vegetale, in: Atti dei Convegni Lincei, Accademia Nazionale dei Lincei, 216, 161-170, 2005.

Dansgaard, W.: Stable isotopes in precipitations, Tellus, 16, 436468, 1964.

de Montety, V., Marc, V., Emblanch, C., Malet, J. P., Bertrand, C., Maquaire, O., and Bogaard, T. A.: Identifying the origin of groundwater and flow processes in complex landslides affecting black marls: insights from a hydrochemical survey, Earth Surf. Proc. Land., 32, 32-48, 2007.

Drever, J. I.: The Geochemistry of Natural Waters: Surface and Groundwater Environments, 3rd Edn., Prentice Hall, Upper Saddle River, 1997.

Duchi, V., Venturelli, G., Boccasavia, I., Bonicolini, F., Ferrari, C., and Poli, D.: Studio geochimico dei fluidi dell' Appennino Tosco-
Emiliano-Romagnolo, Boll. Soc. Geol. It., 124, 475-491, 2005.

Fazlagic, S., Lombroso, L., and Quattrocchi, S.: Osservazioni meteorologiche 2004 a Modena e Ferrara, Atti Societa Naturalisti e Matematici di Modena, 135, 5-40, 2004.

Ferronsky, V. J. and Polyakpov, V. A.: Isotopes of the Earth's Hydrosphere, Springer-Verlag, New York, 682 pp., 2012.

Fetter, C. W.: Applied Hydrogeology, Prentice Hall, 691 pp., 2001.

Freeze, R. A. and Cherry, J. A.: Groundwater, Prentice-Hall, Englewood Cliffs, NJ, 604 pp., 1979.

Gargini, A., Vincenti, V., Piccinini, L., Zuppi, G. M., and Canuti, P.: Groundwater flow systems in turbidites of the northern Apennines (Italy): natural discharge and high speed railway tunnel drainage, Hydrogeol. J., 16, 1577-1599, 2008.

Gibson, J. J., Edwards, T. W. D., Birks, S. J., St Amour, N. A., Buhay, W. M., McEachern, P., Wolfe, B. B., and Peters, D. L.: Progress in isotope tracer hydrology in Canada, Hydrol. Process., 19, 303-327, 2005.

Gonfiantini, R., Dincer, T., and Derekoy, A. M.: Environmental isotope hydrology in the Honda region, Algeria, Isotope Techniques in Groundwater Hydrology, IAEA, Vienna, 1, 293-316, 1974.

Gran, G.: Determination of the equivalence point in the potentiometric titrations, Analyst, 77, 661-671, 1952.

Grew, E. S. and Anovitz, L. M.: Boron: mineralogy, petrology and geochemistry, Rev. Mineral., 33, 864 pp., 1996.

Guglielmi, Y., Bertrand, C., Compagnon, F., Follacci, J. P., and Mudry, J.: Acquisition of water chemistry in a mobile fissured basement massif: its role in the hydrogeological knowledge of the La Clapiere landslide (Mercantour massif, Southern Alps, France), J. Hydrol., 229, 138-148, 2000.

Heinicke, J., Italiano, F., Koch, U., Martinelli, G., and Tedesca, L.: Anomalous fluid emission of a deep borehole in a seismically active area of northern Apennines (Italy), Appl. Geochem., 25, 555-571, 2010.

Hutchinson, J. N.: A coastal mudflow on the London Clay cliffs at Beltinge, North Kent, Geotechnique, 20, 412-438, 1970.

Iacumin, P., Venturelli, G., and Selmo, E.: Isotopic features of rivers and groundwater of the Parma Province (northern Italy) and their relationships with precipitation, J. Geochem. Explor., 102, 5662, 2009.

Iverson, R. M. and Major, J. J.: Rainfall, groundwater flow, and seasonal motion at Minor Creek landslide, Northwestern California: physical interpretation of empirical relations, Geol. Soc. Am. Bull., 99, 579-594, 1987.

Kendall, C. and Caldwell, E. A.: "Fundamentals of Isotope Geochemistry", in: Isotope Tracers in Catchment Hydrology, edited by: Kendall, C. and McDonnell, J. J., Elsevier Science, Amsterdam, 51-86, 1998.

Kendall, C. and McDonnell, J. J.: Isotope tracers in Catchment Hydrology, Elsevier Sciences, Amsterdam, 839 pp., 1998.

Keren, R. and Mezuman, U.: Boron adsorption by clay minerals using phenomenological equation, Clay. Clay Miner., 29, 198204, 1981.

Kligfield, R.: The northern Apennines as a collisional orogen, Am. J. Sci., 279, 676-691, 1979.

Longinelli, A. and Selmo, E.: Isotopic composition of precipitation in Italy: a first overall map, J. Hydrol., 270, 75-88, 2003.

Longinelli, A., Anglesio, E., Flora, O., Iacumin, P., and Selmo, E.: Isotopic composition of precipitation in Northern Italy: Reverse effect of anomalous climatic events, J. Hydrol., 329, 471-476, 
2006.

Martinelli, G. and Dadomo, A.: Geochemical model of mud volcanoes from reviewed worldwide data, short review, in: Mud Volcanoes, Geodynamics and Seismicity, NATO Sciences Series IV: Earth and Environmental Sciences, 51, 211-220, 2005.

Martinelli, G. and Judd, A.: Mud volcanoes of Italy, Geol. J., 39, 49-61, 2004.

Martinelli, G., Bassignani, A., Ferrari, G., and Finazzi, P. B.: Predicting earthquakes in northern Apennines: recent developments in monitoring Radon-222, in: Proceedings of the 4th Int. Symp. on the Analysis of Seismicity and Seismic Risk, 192-208, Bechyne Castel, Czechoslovakia, 2-8 September 1989.

Martinelli, G., Cremonini, S., and Samonati, E.: Geological and geochemical setting of natural hydrocarbon emissions in Italy, edited by: Al-Megren, H. A., Advances in Natural Gas Technology, 79-120, 2012.

Mather, J. and Porteous, N. C.: The geochemistry of boron and its isotopes in groundwaters from marine and non-marine sandstone aquifers, Appl. Geochem., 16, 821-834, 2001.

Mazor, E.: Chemical and Isotopic Groundwater Hydrology, Marcel Dekker Inc., New York, 413 pp., 1997.

Minissale, A. and Vaselli, O.: Karst springs as "natural" pluviometers: Constraints on the isotopic composition of rainfall in the Apennines of central Italy, Appl. Geochem., 26, 838-852, 2011.

Minissale, A., Magro, G., Martinelli, G., Vaselli, O., and Tassi, F.: Fluid geochemical transect in the northern Apennines (CentralNorthern Italy): fluid genesis and migration and tectonic implications, Tectonophysics, 319, 199-222, 2000.

Molli, G.: Northern Apennine-Corsica orogenic system: an update overview, Geol. Soc. Spec. Publ., 298, 413-442, 2008.

Papani, G., De Nardo, M. T., Bettelli, G., Rio, D., Tellini, C., and Vernia, L.: Note Illustrative della Carta Geologica d'Italia alla scala $1: 50.000$, Foglio 218 Castelnovo Ne' Monti, Servizio Geologico d'Italia, Roma, 139 pp., 2002.

Parkhurst, D. L. and Appelo, C. A. J.: PHREEQC2 user's manual and program, Water-Resources Investigations Report, US Geological Survey, Denver, Colorado, 2004.

Ronchetti, F., Borgatti, L., Cervi, F., Gorgoni, C., Piccinini, L., Vincenzi, V., and Corsini, A.: Groundwater processes in a complex landslide, northern Apennines, Italy, Nat. Hazards Earth Syst. Sci., 9, 895-904, doi:10.5194/nhess-9-895-2009, 2009.

Simpson, H. J., Hamza, M. S., White, J. W. C., Nada, A., and Awad, M. A.: Evaporative enrichment of deuterium and $\delta^{18} \mathrm{O}$ in arid zone irrigation, Isotopes techniques in Water Resources Development, IAEA Symposium, 299, Vienna, 241-256, 1987.

Taylor, J. R.: An Introduction to Error Analysis: The Study of Uncertainties in Physical Measurements, University Science Books, 2nd Edn., Sausalito, CA, 1997.

Tazioli, A.: Landfill investigation using tritium and isotopes as pollution tracers, Acquae Mundi, 89-92, 2011.

Thatcher, L. L., Janzer, V. J., and Edwards, R. W.: Methods for determination radioactive substances in water and fluvial sediments, in: Techniques of Water Resources Investigations, US Geological Survey, Washington, 79-81, 1977.
Thornthwaite, C. W. and Mather, J. R.: Instruction and tables for computing potential evapotraspiration and the water balance, Publ. Clim. Drexel Inst. Technol., 10, 185-311, 1957.

Tóth, J.: Groundwater as a geological agent: an overview of the causes, processes, and manifestation, Hydrogeol. J., 7, 1-14, 1999.

Tóth, J.: Gravitational Systems of Groundwater Flow: Theory, Evaluation, Utilization, Cambridge University Press, Cambridge, 297 pp., 2009.

Toscani, L., Venturelli, G., and Boschetti, T.: Sulphide-bearing waters in northern Apennines, Italy: general features and water-rock interaction, Aquat. Geochem., 7, 195-216, 2001.

UNMIG (National Mining Office for hydrocarbon and geothermal energy) VIDEPI Project: Visibility of petroleum exploration data in Italy, http://unmig.sviluppoeconomico.gov.it/videpi/en/, 2007.

USGS: A simple field leach test to assess potential leaching of soluble constituents from mine wastes, soils, and other geologic materials, USGS Fact Sheet, Denver, Colorado, 2005-3100, 2005.

van Asch, T. W. J., Buma, J., and Van Beek, L. P. H.: A view on some hydrological triggering systems in landslides, Geomorphology, 30, 25-32, 1999.

Vannucchi, P. and Bettelli, G.: Myths and recent progress regarding the Argille Scagliose, Northern Apennines, Italy, International Geology Review, 52, 1106-1137, 2010.

Vannucchi, P., Remitti, F., and Bettelli, G.: Geological record of fluid flow and seismogenesis along an erosive subducting plate boundary, Nature, 451, 699-703, 2008.

Venturelli, G., Boschetti, T., and Duchi, V.: Na-carbonate waters of extreme composition: possible origin and evolution, Geochem. J., 37, 351-366, 2003.

Walker, C. T.: Geochemistry of Boron, Dowden, Hutchinson \& Ross, Benchmark Papers in Geology, Stroudsburg, PA, 23, 414 pp., 1975.

White, D. E.: Saline waters of sedimentary rocks, Am. Assoc. Petr. Geol. Mem., 4, 342-366, 1965.

WISER: Water Isotope System for data analysis, visualization and Electronic Retrieval, database of Global Network of Isotopes in Precipitation (GNIP) of the International Atomic Energy Agency (IAEA), available at: http://www.univie.ac.at/ cartography/project/wiser/ (last access: 6 September 2012), 2012.

Wieczorek, G. F.: Landslide triggering mechanisms, in: Landslides Investigation and Mitigation, edited by: Turner, A. K. and Schuster, R. L., special report, 247, National Academy Press, Washington DC, 1996.

WP/WLI: Working Party on the World Landslide Inventory and Canadian Geotechnical Society, Multilingual Landslide Glossary, edited by: Richmond, B. C., BiTech Publishers, British Columbia, Canada, 59 pp., 1993. 